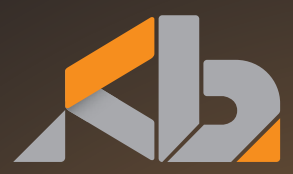

KENYA BANKERS

ASSOCIATION

One Industry. Transforming Kenya.

\title{
Sustainability in the Financial Sector in Kenya
}

Francis Kariuki

KBA Centre for Research on Financial Markets and Policy ${ }^{\circledR}$ Working Paper Series 


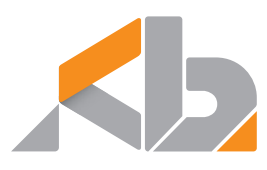

\section{KENYA BANKERS}

ASSOCIATION

One Industry. Transforming Kenya.

\section{Working Paper Series}

\section{Centre for Research on Financial Markets and Policy}

The Centre for Research on Financial Markets and Policy was established by the Kenya Bankers Association in 2012 to offer an array of research, commentary, and dialogue regarding critical policy matters that impact on financial markets in Kenya. The Centre sponsors original research, provides thoughtful commentary, and hosts dialogues and conferences involving scholars and practitioners on key financial market issues. Through these activities, the Centre acts as a platform for intellectual engagement and dialogue between financial market experts, the banking sector and the policy makers in Kenya. It therefore contributes to an informed discussion that influences critical financial market debates and policies.

The Kenya Bankers Association (KBA) Working Papers Series disseminates research findings of studies conducted by the KBA Centre for Research on Financial Markets and Policy. The Working Papers constitute "work in progress" and are published to stimulate discussion and contribute to the advancement of the banking industry's knowledge of matters of markets, economic outcomes and policy. Constructive feedback on the Working Papers is welcome. The Working Papers are published in the names of the author(s). Therefore their views do not necessarily represent those of the KBA.

The entire content of this publication is protected by copyright laws. Reproduction in part or whole requires express written consent from the publisher.

C) Kenya Bankers Association, 2015 


\title{
Sustainability in the Financial Sector in Kenya
}

\author{
By Francis Kariuki*
}

February 2015

\section{Abstract}

At the core of the concept of sustainability is the need to take into account the social, economic and environmental concerns in development. Sustainability ensures that economic growth takes into consideration social and environmental issues. In the financial sector, sustainability is necessary due to the critical role played by the sector in national development. In Kenya, financial institutions are financing investments in the agricultural, manufacturing, housing, infrastructural, energy and extractive industries. These investments have significant environmental and social impacts creating the need for adoption of sustainable finance. In spite of this, initiatives aimed at sustainability in the sector, are diverse and uncoordinated, and are therefore not likely to result in tangible long term benefits for society, environment and the business community. A synergistic approach to sustainability in the industry is thus imperative. The paper proposes the adoption of a hybrid approach in implementing sustainable banking in Kenya. The model would harness the positive attributes of market-driven and compliance approaches to regulation. Such a model could have voluntary codes and guidelines developed by the industry, and a regulator to enforce and ensure compliance with those guidelines.

* Strathmore Law School 


\section{Introduction}

$\mathbf{T}$

his study sought to explore the initiatives being undertaken by banks

towards sustainable banking in Kenya. In particular, the study sought to find out the sustainability initiatives the banks under survey had adopted in their operations and activities. And secondly, the study aimed at making recommendations on the implementation of sustainable banking.

Sustainable banking is a business strategy that balances economic, social and environmental issues in business. It integrates social and environmental considerations in lending decisions; ensures good governance, transparency and integrity; promotes environmental protection; embeds resource efficiency and brings about financial inclusion by supporting small and medium enterprises. ${ }^{2}$ It also refers to a decision by banks to provide products and services only to those customers who take into account environmental and social issues in their work. Babalola describes sustainability in banking, as a value system stipulating that a bank's commercial activities must benefit its staff, shareholders, customers and the economy and conserves the natural environment. ${ }^{4}$ The role of financial institutions in development actuates the need for sustainability. According to Jeucken, 'their role is an intermediary one, transferring money by space, term, scale and risk. This function thus affects the development and direction of the economy... ${ }^{15}$

1 IFC, "Sustainable and Responsible Banking in Africa-A Getting Started Guide," available at http://www.ifc.org/wps/wcm/connect/a38d2c8043fegffc8f87bf869243d457/Sustainable +and+Responisble+Banking.pd??MOD=AJPERES, accessed on 11/12/2014.

2 lbid.

3 IFC, "Banking on Sustainability: Financing Environmental and Social Opportunities in Emerging Markets," (IFC, 2007).

4 A. Babalola, "Corporate Governance and Sustainable Banking Sector: Evidence from Nigeria," Research Journal of Finance and Accounting, Vol.5, No.12, 2014, pp. 32 - 43.

5 M. Jeucken, Sustainable Finance and Banking; The Financial Sector and the Future of the Planet, Earth scan Publications, London, 2002, p.52. 
However, financial services and products extended by financial institutions have adverse effects on the environment, human rights, society and the economy.6 In effect, banks must be cognizant of the social, environmental, credit, reputational and compliance risks they may be exposed to? Moreover, financial institutions operate within a web of complex and competing interests with diverse expectations. This requires a balancing of the diverse expectations and weighing the impact of their

6 J.W.Gelder, "The do's and don'ts of Sustainable Banking: A Bank Track Manual," available at www.banktrack.org/.../061129 the dos and donts of sustainablebanking, (accessed on 2/08/2014).

7 lbid. decisions on the different actors. ${ }^{8}$

The paper proceeds in seven parts. Part I is the introduction and structural outline of the paper. Part II offers some background to the study. Part III contains the literature review. Part IV discusses the research methodology. Part V contains the data. Part VI outlines the findings and an analysis of the data. Part VII concludes and gives the recommendations.

8 A.M.E. Mendoza \& C.T. Toralba, 'Shareholder Value and the Common Good,' in D. Lutz \& P. Mimbi, The Challenge of Business: Going Beyond Wealth Maximisation and Profit Maximisation, (Law Africa, 2011), pp. 112-114. 


\section{Background to the Research}

\subsection{An Overview of the Financial Sector in Kenya}

The financial sector in Kenya is bank-led explaining why the banking sub-sector is leading the current efforts towards sustainable finance. Banks are not only doing traditional commercial banking. Top commercial banks have departments dealing with investment, insurance, microfinance, custodial services, private equity ventures and engagement with the capital markets to raise long term funding.

Currently, the financial sector is comprised of the Central Bank of Kenya as the regulator, ${ }^{9}$ forty four (44) commercial banks, one (1) mortgage finance company, seven (7) representative offices of foreign banks, nine (9) microfinance institutions, two (2) credit reference bureaus and one hundred and one (101) forex bureaus ${ }^{10}$ The main laws governing the sector are the Constitution of Kenya 2010, the Banking Act, ${ }^{11}$ the Central Bank of Kenya Act, ${ }_{1}^{12}$ the Microfinance Act, 2006, ${ }^{13}$ the Companies Act, ${ }^{14}$ the Building Societies $\mathrm{Act}_{1}^{15}$ the Prudential Guidelines issued by the Central Bank of Kenya and recently the Consumer Protection Act, 2012. ${ }^{16}$

The Central Bank of Kenya classifies banks according to shareholding or listing in the Nairobi Securities Exchange. According to shareholding, banks are categorized as foreign owned, banks with government

\footnotetext{
9 Sections 4 and 4A, Central Bank of Kenya Act, Chapter 491, Laws of Kenya.

10 Central Bank of Kenya, Bank Supervision Annual Report, 2013, p.1.

11 Chapter 488, Laws of Kenya.

12 Chapter 491, Laws of Kenya.

13 Chapter 493D, Laws of Kenya.

14 Chapter 486, Laws of Kenya.

15 Chapter 489, Laws of Kenya.

16 Act. No.46 of 2012.
} 
participation or locally owned banks. Foreign owned banks are further grouped into three. First, there are foreign owned banks, which are incorporated outside Kenya such as Habib Bank, Citi Bank and Bank of India. Second, there are those incorporated in Kenya but partly owned by foreign institutions and locals such as Barclays, Bank of Baroda, Ecobank, Diamond Trust, Gulf Africa, K-Rep, Standard Chartered Bank and First Community Bank. Third, there are banks that are wholly owned foreign banks but incorporated in Kenya and include Bank of Africa and United Bank of Africa. Banks with government participation include CFC Stanbic, Consolidated Bank, Kenya Commercial Bank, Development Bank of Kenya, National Bank and Housing Finance bank. Locally owned banks are thirty in number. ${ }^{17}$ Institutions listed on the Nairobi Securities Exchange include Barclays Bank of Kenya Ltd, CFC Stanbic Bank Ltd, Equity Bank Ltd, Housing Finance bank, Kenya Commercial Bank Ltd, NIC Bank Ltd, Standard Chartered Bank (K) Ltd, Diamond Trust Bank Kenya Ltd, National Bank of Kenya and Cooperative Bank of Kenya Ltd.

The financial sector will be crucial in delivering the envisioned 10\% economic growth rate per annum in Kenya. ${ }^{18}$ Already, the sector has contributed

17 Central Bank of Kenya, "Shareholding Information,"CBKWebsite, 2014, available at https://www.centralbank.go.ke/index.php/commercialbanks-mortgage-finance-institutions/shareholding-information, accessed on 28/10/2014.

18 National Climate Change Action Plan, Mainstreaming Kenya's National Climate Change Action Plan into the Financial Services Sector, 2012, p.1. See also Republic of Kenya, Vision 2030, Government of Kenya, 2007, p.72. immensely towards the country's prosperity by, inter alia, enhancing financial intermediation, promoting financial inclusion, employment creation and payment of taxes to the government. For example, gross loans and advances to the different sectors of the economy stood at 1.78 billion in June 2014. ${ }^{19}$ An increasing number of small and medium-sized enterprises are now able to access funding from commercial banks. For example, in 2013 there was a 17.4\% proportion of total lending being directed to SMEs. ${ }^{20}$ Commercial banks are also investing in community development projects. In 2013, banks allocations towards highimpact corporate social investment amounted to Kshs. 1.4 billion. ${ }^{21}$ It is also one of the highest tax contributors, contributing approximately Kshs. 37 billion in corporate taxes alone in 2013. ${ }^{22}$ Banks are therefore playing a vital role in driving economic growth and development, and hence the need for sustainability.

\subsection{Sustainable Banking}

Classical and neo-classical scholars viewed development as progress, as economic growth or 'change' in man and society, which increases in quantitative and qualitative terms ${ }^{23}$ The process of

19 Kenya Bankers Association, Banking Industry Development and Social Investment Report, 2013.

20 lbid.

21 lbid.

22 lbid.

230. Owiti, "Law, Ideology and Development: Dialectics or Eclecticism at Play?" in Y. Vyas et al (eds), Law and Development in the Third World, (University of Nairobi, 1994), pp. 18-19. 
development was also seen as a series of successive stages of economic growth through which all countries must undergo ${ }^{24}$ By focusing on economic growth only, the development process was ignoring the social and environmental pillars of development. With time, it was realized that there was need to integrate the social and environmental concerns in development. This led to the formulation of the principle of sustainable development.

Sustainable banking is informed by the principle of sustainable development. Sustainable development means "development that meets the needs of the present without compromising the ability of future

24 M.P. Todaro, Theories of Development: A Comparative Analysis, (Addison Wesley, 2000), pp.77-78. generations to meet their own needs "25 Strange and Bayley view sustainable development as a holistic and balanced conceptual framework; as a process of applying the principles of integration, across space and time in decision-making; and an end goal that identifies and fixes the specific problems of resource depletion, health care, social exclusion, poverty, unemployment, amongst others. ${ }^{26}$ Society, economy and the environment are the pillars of sustainable development ${ }^{27}$ As shown in Figure 1, the three pillars are interrelated and interdependent. Ignoring one of these pillars leads to global crisis like climate change.

25 WCED, Our Common Future (Oxford: Oxford University Press, 1987), p.8.

26 T. Strange \& A. Bayley, Sustainable Development: Linking Economy, Society, Environment, (OECD, 2008), p.30.

27 Ibid, pp. 27-28.

\section{Figure 1: A Triple Bottom Line (TBL) Model Showing the Interdependency of Sustainability Pillars}

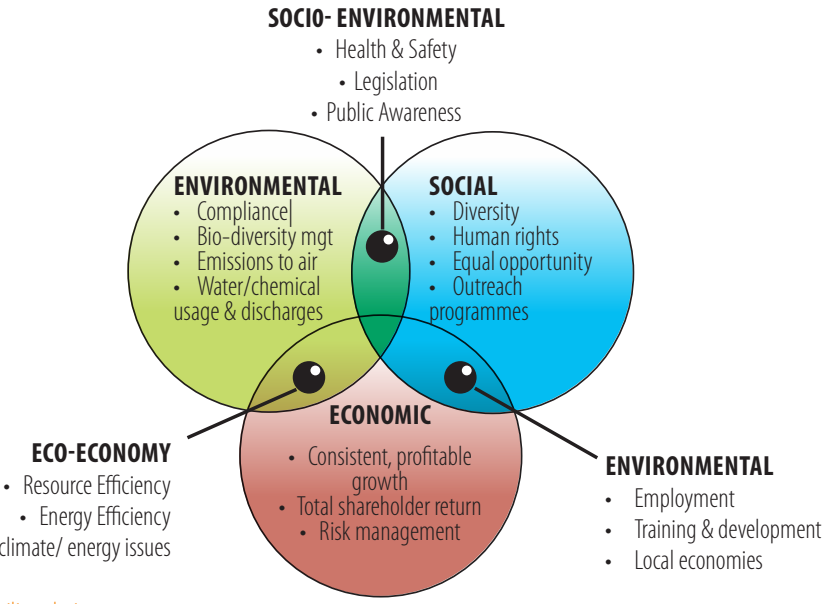


The report of the World Commission on Environment and Development (WCED), Our Common Future, in 1987 highlighted the interdependence of human beings, the economy, environment and society. In 1992, the Rio Conference adopted Agenda 21 as its action plan. The role of business and industry in achieving sustainable development is specifically recognized in Agenda $21{ }^{28}$ It stipulates that increasing prosperity, as a goal of the development process, is contributed primarily by the activities of business and industry. ${ }^{29} \mathrm{It}$ further states that, the improvement of production systems through technologies and processes that utilize resources more efficiently and at the same time produce less wastes; is an important pathway towards sustainability for business and industry. Additionally, it recognizes that facilitating and encouraging inventiveness, competitiveness and voluntary initiatives are necessary for stimulating more varied, efficient and effective options. ${ }^{30}$

The emergence and popularization of sustainable development, has led to concerted efforts by the private sector to integrate sustainability in their operations and activities. Leading institutions in the financial sector have formulated sustainability guidelines for adoption in the sector. These guidelines include, the Global Reporting Initiative (GRI), launched

28 United Nations Conference on Environment and Development, Rio de Janerio, Brazil, June 1992, Agenda 21, available http:// sustainabledevelopment.un.org/content/documents/Agenda21.pdf accessed 12th August 2014, Chapter 30.

29 Ibid, paragraph 30.1.

30 Ibid, paragraph 30.4. by UNEP in 1997 to promote sustainability reporting..$^{31}$ The UN Global Compact initiative established in 2000 aiming at having 'a more sustainable and inclusive global economy. ${ }^{32}$ The International Finance Corporation (IFC) sustainability strategy focuses on transforming markets, driving innovation and adding value to clients by helping them improve their business performance. IFC also ensures economic benefits are shared with the poor and vulnerable, and that development takes place in an environmentally and socially sustainable manner. ${ }^{33}$ IFC is a leader in promoting economic sustainability. Most banks adopt sustainability principles and environmental, social and governance (ESG) standards so that they can access funding from international sources. ${ }^{34}$ Other development finance institutions influencing adoption of sustainable finance include German Investment Corporation (DEG), the Netherlands Development Finance Company (FMO), the French Agency for Development (AFD) and African Development Bank (AfDB).

The first significant step by private banks towards sustainability came in 2003, when the Equator Principles were adopted. The Principles are based on

31 Global Reporting Initiative, available at https://www.globalreporting. org/information/about-gri/Pages/default.aspx, accessed on 10/11/2014.

32 United Nations Global Compact, "The Ten Principles", available at www.unglobalcompact.org/abouttheG/TheTenprinciples/index.html. (accessed on 16/06/2014).

33 International Finance Corporation, The Business Case for Sustainability, IFC, 2012, p.6.

34 Best Practice Guide on Sustainable Finance, 2012 available at www. wwfru/data/docs/best-practice-guide-for-banks.doc, pp. 15-18. 
the IFC's environmental and social safeguard policies. They provide banks with a framework for reviewing, evaluating and mitigating or avoiding environmental and social impacts and risks associated with projects they finance. ${ }^{35}$ The United Nations Environment Programme Financial Initiative (UNEP FI), is a global partnership between UNEP and the financial sector, and considers the impacts of environmental and social considerations in financial performance.

\subsection{Pillars of Sustainable Banking}

\subsubsection{Economic sustainability}

Economists view sustainability as a way of defending economic efficiency. ${ }^{36}$ Due to resource scarcity, they should be allocated efficiently to maximize their utility. ${ }^{37}$ The operations and activities of an organization should contribute to overall economic growth and stability, with minimal negative impact on the environment or society. Economic sustainability also entails the adoption of risk management guidelines that guide banks in

35 Available at http://www.equator-principles.com, accessed on 29/10/2014

36 I. Sundar, Environment and Sustainable Development, (APH Publishing, 2006), pp.95-96.

37 J. Harris, "Basic Principles of Sustainable Development," Global Development and Environment Institute, Working Paper 00-04 available at hitps://notendur.hi.is/bdavids/UAU101/Readings/ Harris 2000 Sustainable development.pdf accessed on 26/06/2014 determining the types of risks they are willing to get involved in. Banks are not to enter into ventures that expose them to financial risks. It also requires banks to have client deposit protection systems and adequate capital for trading purposes. Economic sustainability also requires the adoption of best practices on sustainability, transparency, accountability, audit of activities so as to keep shareholders and stakeholders informed including reporting on the salaries of top executives and the board. ${ }^{38}$ In essence, sustainability should proffer profits to a company. The correlation between profitability and sustainability has been shown empirically in a recent study conducted by the Harvard Business School and the London Business School. The study compared the performance of 'highsustainability' versus 'low sustainability' companies between 1993 and 2009, and found that 'highsustainability' companies significantly outperformed their counterparts. ${ }^{39}$ (See Figure 2) The IFC guidelines and the Equator Principles are notable in their emphasis on economic sustainability in the financial sector.

38 M. Imeson \& A. Sim, "Sustainable Banking: Why Help Communities and Saving the Planet is Good for Business", available athttp://www. sas.com/resources/whitepaper/wp 24356.pdf accessed on 23rd June 2014, p. 5; A. Hoijtink, "The Sustainability Attitude of Commercial Banks,"University of Tilburg, September 2005, p. 36.

39 R.G. Eccles, I. loannou \& G. Serafeim, 'The Impact of Corporate Sustainability on Organizational Processes and Performance,' available at http://www.hbs.edu/faculty/Publication\%20Files/ SSRN-id1964011 6797edac-7daa-4603-a220-4a0c6c7a3f7a.pdff. accessed on 12/08/2014, pp. 1-46. 


\section{Figure 2: Sustainability versus Profitability}

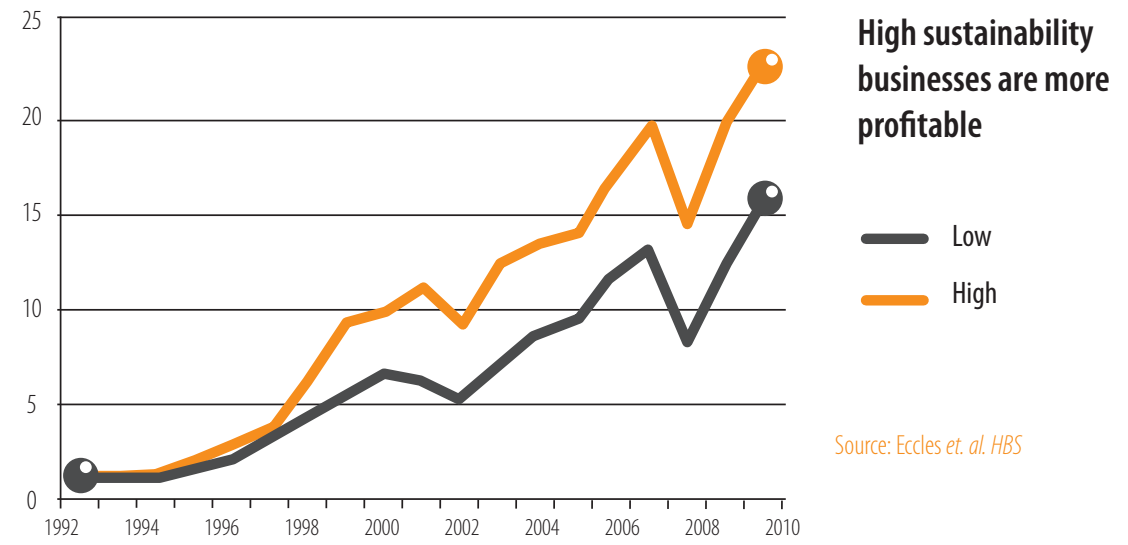

\subsubsection{Social Sustainability}

Social sustainability relates to the social dimension of the activities and operations of banks. ${ }^{40}$ Corporations do not operate in a vacuum. They must ensure fairness in distribution of opportunities, promote social ventures like health and education, gender equity, political accountability, transparency and public participation. ${ }^{41}$ Social sustainability also requires employee training and development, workplace health and safety, hiring of staff from diverse backgrounds, preservation of local cultures, provision of products and services for disadvantaged groups and representation of stakeholders' interests,

40 A. Hoijtink, "The Sustainability Attitude of Commercial Banks," University of Tilburg, September 2005, p. 36.

41 Jonathan M. Harris, "Sustainability and Sustainable Development," available at http://isecoeco.org/pdf/susdev.pdf accessed on 24th June 2014. local communities and minority shareholders. ${ }^{42}$ It also requires a commitment to internationally recognized standards such as ISO 26000:2010. ISO 26000:2010 provides guidelines to businesses on how to operate in a socially responsible way. Other best practices on social sustainability are the IFC standards, International Labour Organisation standards, ${ }^{43}$ UN Global Compact guidelines, UNEP FI Guide to Banking and Sustainability, the Equator Principles, GRI Sustainability Reporting Guidelines and the Global Sullivan Principles.

42 A. Hoijtink, "The Sustainability Attitude of Commercial Banks," University of Tilburg, September 2005, pp. 38-39.

43 See for example, the ILO Declaration on Fundamental Principles and Rights at work. The principles and rights at work covered under the Declaration are: freedom of association and right to collective bargaining; elimination of all forms of forced or compulsory labour; effective abolition of child labour; and elimination of discrimination in employment and occupation. 


\subsubsection{Environmental Sustainability}

The third dimension of sustainable development is environmental sustainability. Overreliance on environmental goods for development purposes is occasioning resource depletion. This has necessitated the need for sustainable use of resources and conservation of the environment. It requires human beings to satisfy their needs, without exceeding the carrying capacity of supporting ecosystems to continue regenerating the services necessary to meet those needs. ${ }^{44}$ Environmental sustainability aims at striking a balance between the productive levels of the environment and the consumption levels of the population. ${ }^{45}$ However, as shown in Figure 3

\footnotetext{
44 R. Yadav \& G.S. Pathak, "Environmental Sustainability through Green Banking: A Study on Private and Public Sector Banks in India, "Available at http://www.ssm.com/link/OIDA-Intl-Journal-Sustainable-Dev. html, (accessed on 10/07/2014).

45 Ibid.
}

below, the costs of adaptation to climate change as a percentage of GDP are expected to be on the rise especially in Africa. Adaptation and mitigation efforts to climate change will require the concerted efforts of all, including the financial sector.

Environmental threats, like climate change, have knock-on effects on key sectors of the economy such as agriculture, tourism, transport and energy. These effects include; economic slowdown, unemployment, migration, rises in commodity prices and volatility in the property market. ${ }^{46}$ Institutional investors like banks, are increasingly getting concerned about the direct and indirect impacts of climate change on their investment portfolios including securities of other financial institutions.

46 Republic of Kenya, National Climate Change Action Plan 2013-2017, Government of Kenya, 2013.

\section{Figure 3: Cost of Environmental Sustainability}

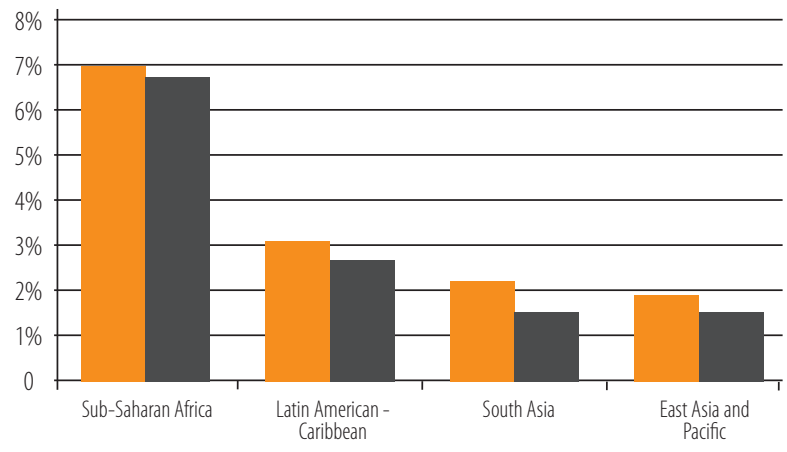

Adaptation Costs as a percentage of GDP

$2010-2019$

$2020-2029$

Source: Based on "Costs to developing Countries of Adapting to Climate Change" World Bank, 2009 
Some of the environmental issues a bank has to consider include: compliance with environmental legislation, air emissions and responses to climate change, energy and resource consumption, ecological footprint, and environmental impacts associated with products and services. Moreover, banks have to review the environmental behavior of their clients, potential contingent liabilities from new legislations, and potential new markets for environmental services and environmentally friendly products. ${ }^{47}$ Internally,

47 A Report of UNEP FI \& ATF, "Banking on Value-A New Approach to Credit Risk," (UNEP, 2007). banks can adopt environmental management systems such as the use of green energy, double sided photocopying, use of recycled paper, provision of staff buses, and good usage of water. Externally, banks can limit financing to projects that are environmentally sound. ${ }^{48}$ UNEP Fl and the large number of international climate funds under the United Nations Framework Convention on Climate Change (UNFCCC) and the Kyoto Protocol are providing incentives for adoption of sustainable finance.

48 A. Hoijtink, "The Sustainability Attitude of Commercial Banks," University of Tilburg, September 2005, p. 35. 


\section{Literature Review}

\subsection{Rationale for Sustainable Banking}

n the finance sector, there are numerous drivers for sustainable finance

as shown in Figure 4. First, banks financing large-scale projects are adopting sustainable finance to avoid reputational risks. Individual clients, shareholders, investors (including International Financial Institutions), clients/ investees and environmental NGOs, usually organize campaigns against banks financing projects with negative impacts on the environment and local communities. Because of such activism, a bank may suffer reputational loss and eventually lose customers.

For example, pressure from NGOs made the World Bank to withdraw financing of the Three Gorge Dam project in China and the Namada Valley Series in India. ${ }^{49}$ According to Thokozani, the adoption of voluntary sustainability programmes, is a management and strategic response to reputational risk ${ }^{50}$ that also benefits the society and natural environment.

Second, failure to conduct environmental, social and economic screening of projects, can negatively affect the performance of investment portfolios. ${ }^{51}$ Since most large-scale projects depend on returns from the project and its assets to repay loans from banks, ${ }^{22}$ failure to do sustainability screening for projects increases clients' credit default risk..$^{53} \mathrm{~A}$ bank that fails to carry out sustainability screening may have no recourse in recouping the extended credit

\footnotetext{
49 lbid.

50 D.H. Thokozani, The Banking Sector's Response to Environmental Sustainability (Thesis, University of Pretoria, 2010), p.75.

51 A. Hoijtink, "The Sustainability Attitude of Commercial Banks," Op. cit, p.9.

52 lbid.

53 lbid.
} 
as the project returns and assets are often the security in project lending. ${ }^{54}$ Therefore, screening is not only a due diligence exercise but one that has impacts on long-term profitability of a bank.

Third, sustainable finance provides banks with an opportunity to develop innovative products and services in new areas. These are products and services that have social and environmental benefits. Such opportunities include; renewable energy, energy efficiency, cleaner production processes and technologies, biodiversity conservation, microfinance, financial services for marginalized groups like youth and women, agency banking, and low-income housing. By developing such products, banks are

54 lbid. able to get new clients, access new markets, attract new capital, generate goodwill and support from stakeholders. 55

Fourth, banks adopt sustainability and environmental, social and governance (ESG) standards to enable them access finance from development financial institutions like IFC, FMO, DEG, AFD, and AfDB. These institutions provide pricing incentives for commercial banks to embed sustainability into their core banking business. Local banks that are compliant with the sustainability frameworks of development financial institutions are able to access direct and indirect funding at reduced interest rates. FM0 was the first development bank to

55 Best Practice Guide on Sustainable Finance, 2012 available at www. wwf.ru/data/docs/best-practice-guide-for-banks.doc, p.12.

\section{Figure 4: Drivers for Banks to Adopt Sustainable Finance Practices*}

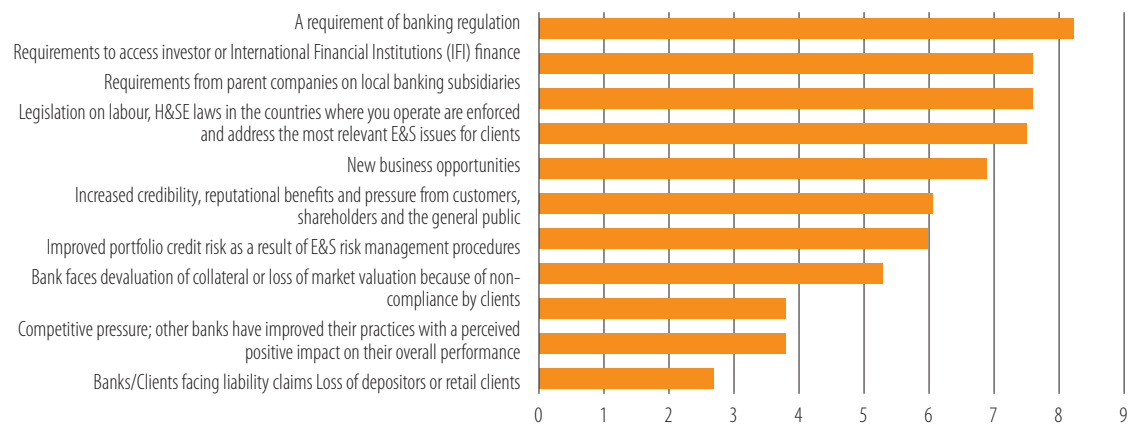

\section{Source: KBA SFI Needs Assessment Report, 2014.}

*The survey assessed 12 Commercial Banks, ranging from large multinationals to a local microfinance. 


\section{Figure 5: Benefits realised from adoption of Sustainable Finance Initiative}

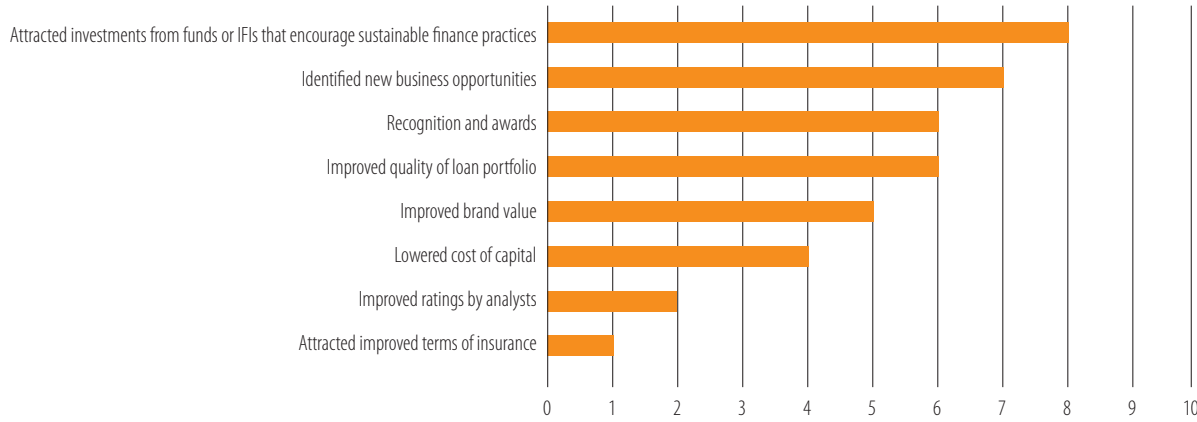

Source: KBA SFI Needs Assessment Report, 2014.

develop a framework offering a reduced interest rate to borrowers who meet environmental, social and good governance (ESG) standards within a set time frame..$^{56}$

Some of the benefits that accrue to banks by adopting sustainability include.:57 improved reputation; access to long-term funding from development finance institutions and government; attracting more clients; increased profitability; increased potential for partnerships; operational cost management and improved relationships with stakeholders. (See Figure 5) In addition, sustainability is distinguishable from corporate social responsibility (CSR) in terms of benefits. Whereas CSR is an after-core business

56 lbid, pp. 15-18.

57 Ibid, p.7. approach, (where the bank carries out programs to benefit the community as a philanthropic exercise), ${ }_{1}^{58}$ sustainable banking is a core-business approach integrated into an organizations management and operations. Additionally, whereas CSR is sporadic, sustainable banking is embedded in business strategy and therefore consistent and long-term. ${ }^{59}$

In spite of the above benefits, sustainable development faces criticisms and constraints from some quarters. (See Figure 6) For example, there are views that community investments lack guaranteed

58 0.K. Edu, "Corporate Social Responsibility: Multinational Oil Companies in Nigeria," Vol. 21, No.1, Journal of the Commonwealth Lawyers Association (2012), pp. 41-51.

59 Ibid. 
returns to banks hence no need to undertake them. ${ }^{60}$ Others argue that through CSR initiatives, banks are already engaging in sustainability work. ${ }^{61}$ Sustainable banking is also viewed as a constraint on banks core business of profit-making, because of the costs incurred in implementing it. ${ }^{2}$ However, recent studies have shown a direct correlation between sustainability

60 J.M. Gathungu \& Z.N. Ratemo, 'An Assessment of the Impact of Corporate Social Responsibility on the Strategic Intent at Standard Chartered Bank Kenya Limited,'International Journal of Education and Research, Vol.1 (5) May 2013, pp.1-2.

61 Comment from a participant during the Presentation of this paper during the KBA conference on 25 and $26^{\text {th }}$ August 2014.

62 F. Amalric, "The Equator principles: A Step towards Sustainability?" Center for Corporate Responsibility Sustainability Working Paper Series, (Working paper No. 1/05, 2005), p.3. and profitability. ${ }^{63}$ Some of the costs are incurred in monitoring, evaluating environmental impact assessments, opportunity costs in losing projects, preparing sustainability reports and in building inhouse capacity. Such costs can be overburdening to smaller banks. ${ }^{64}$ Other constraints to sustainable banking include, lack of support from bank officials to the concept and poor enforcement of environmental laws.

63 R.G. Eccles, I. Ioannou \& G. Serafeim, 'The Impact of Corporate Sustainability on Organizational Processes and Performance,' available at http://www.hbs.edu/faculty/Publication\%20Files/ SSRN-id1964011 6791edac-7daa-4603-a220-4a0c6c7a3f7a.pdf. accessed on 12/08/2014, pp. 1-46.

64 A. Hoijtink, "The Sustainability Attitude of Commercial Banks," Op. cit, p.10.

\section{Figure 6: Constraints to Banks Adopting Sustainable Finance Practices}

Absence of internal capacity in banks to understand E\&S impacts of client activities

Absence of consistency in enforcement of E\&S laws

Absence of sector-specific guidelines and other guidance material to help bankers identify and manage related E\&S risks

Absence of relveant banking regulations, standards and guidelines

Absence of business case for E\&S risk management

Banks perceive sustainable finance practices as competitive disadvantage e.g. E\&S risk mgt in credit appraisal processes

Absence of an enabling environment - focus is on short term earnings and less if any attention paid to non-finance reporting

Absence of qualified and affordable advisors in this field

Lack of additional funding in banks to develop E\&S policies and procedures

Absence of senior management support for commitment to E\&S performance

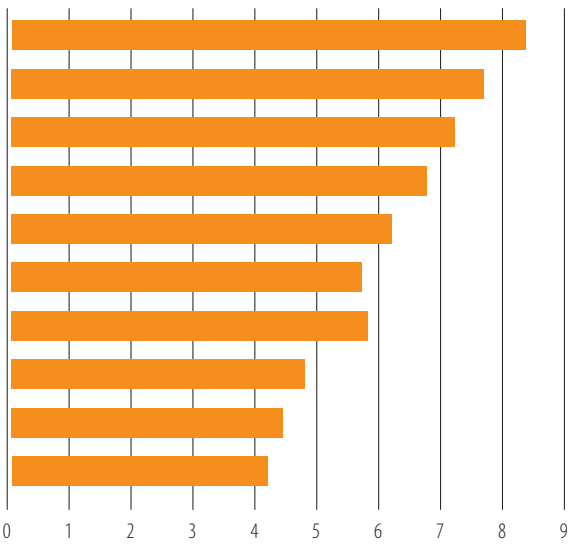




\subsection{Sustainability and the Law}

Law has been described as society's architecture for the attainment of common purposes and aspirations, including sustainability. ${ }^{65}$ In fact, a link has been established between sustainability and legal compliance. According to Zaelke, Stilwell, \& Young, '... sustainable development depends upon good governance, good governance depends upon the rule of law, and rule of law depends upon effective compliance. ${ }^{\prime 6}$ However, law is not the only governance framework in society. ${ }^{67}$ There are other governance frameworks not pegged on the law. Sustainability initiatives can thus be anchored on statutory frameworks, voluntary codes or a merger of the two. Sustainability premised on statutory frameworks results in what is described as a'comply or else' regime or a'one size fits all' which can be problematic. A'one size fits all' approach fails to appreciate the diversity among companies in terms of type of business, size and internal capacities. Other arguments against a compliance regime are the costs of compliance, tendency of boards to focus on compliance at the expense of business and the fact that strong regulation

65 Hernando de Soto, "Making Sustainable Development Work: Governance, Finance, and Public-Private Cooperation," remarks at the Meridian International Center, Washington, DC, 18th October, 2001, available at $h t t p: / / W W w$.state.gov/g/oes/rls/rm/6811.htm, accessed on $12 / 12 / 2014$.

66 D. Zaelke, M. Stilwell \& 0. Young, 'Compliance, Rule of Law \& Good Governance-What Reason Demands: Making Law Work for Sustainable Development,' 2005, available at http://inece.org/m/w/ Chapter1_ZaelkeStilwellYoung.pdf, accessed on 12/12/2014.

67 Ibid. can stifle innovation and entrepreneurship. ${ }^{68}$ This explains the existence of both compliance and market-led approaches towards sustainability in most jurisdictions.

For example, in South Africa there is a South African National Strategy on Sustainable Development (NSSD) providing a framework for integrating economic, social and environmental factors in development. ${ }^{69}$ In addition, there is a National Environmental Management $\mathrm{Act}^{70}$ which requires that social, environmental and economic factors be integrated in planning, decision-making and implementation of development programmes. Legalization of sustainable development has in turn led to the adoption of voluntary codes by corporations since failure to comply attracts fines. ${ }^{71}$ The Johannesburg Securities Exchange (JSE) requires listed companies to adhere to sustainability guidelines via the King Reports on Corporate Governance and Code (King III is the latest version). ${ }^{72}$ King III recognizes the need for sustainability as a moral and economic imperative and source of both opportunities and risks for businesses. The King III principles apply to all entities regardless of the manner and form of their incorporation and sector,

68 Institute of Directors Southern Africa, 'King Code of Governance for South Africa 2009,'pp. 5-6.

69 Department of Environmental Affairs and Tourism, South African Environment outlook, 2006.4

70 Act No. 107 of 1998.

71 D.H. Thokozani, "The Banking Sector's Response to Environmental Sustainability," Op. cit, p. 68.

72 B.J. Richardson, "Africa: from object to agent of socially responsible investment," in F.N. Botchway (ed), Natural Resource Investment and Africa's Development, (Edward Elgar Publishing, 2011), p.270. 
whether public, private or non-profit. Moreover, King III adopts an 'apply or explain' governance framework. Under the framework, the board of directors may adopt a different practice from the one recommended in King III, if it is in the best interest of the company but must explain it. Explaining the different practice adopted and an acceptable reason for it, results in consistency with King III principles. The framework allows entities to tailor the King III principles as appropriate to the size, nature and complexity of their organization. ${ }^{73}$ The King Reports have been used by the JSE as a listing criterion and a tool for underpinning its Sustainable and Responsible Investment (SRI) Index.

In Kenya as well, sustainability is anchored in the law. Under Article 10(2) (d) of the Constitution, sustainable development is a national value and principle of governance binding every person and state organ. In addition, Article 69(2) of the Constitution obligates every person to co-operate with state organs and other persons to protect and conserve the environment and ensure ecologically sustainable development and use of natural resources. Reading the foregoing provisions in conjunction with Article 3 , which requires every person to respect, uphold and protect the Constitution, it is evident that banks have a duty to pursue sustainability in their operations and lending activities.

In 2010, Kenya launched the National Climate Change Response Strategy (NCCRS), to provide a basis for

73 Institute of Directors Southern Africa, 'King Code of Governance for South Africa 2009! strengthening and focusing nation wide action towards climate change adaptation and mitigation. ${ }^{74}$ The National Climate Change Action Plan was developed in 2012 to provide a framework for implementation of the NCCRS, the Constitution 2010 and attainment of Vision 2030. As the implementation of the Action Plan will require access to substantial resources, the government is putting in place the necessary enabling environment to attract climate friendly investments in key sectors of the economy; set up a dedicated climate fund to receive contributions from all sources including public, private and international; and facilitate carbon trading opportunities. ${ }^{75}$ (See Table 1 \& 2 below) A Climate Change Bill 2014, is already under review and, among other things, it establishes a Climate Change Fund to provide longterm finance to project developers. Kenyan banks, as sources of climate finance, are expected to play a key role in supporting the transition to a low-carbon and climate-resilient economy. This is because the Action Plan proposes to use the Fund to provide concessional credit lines to banks to lend on to firms on favourable terms and building on existing programmes. ${ }^{76}$ This will create an incentive for local banks to adopt sustainable finance so as to access funding from the Fund and from development finance institutions such as IFC and AfDB at low interest rates.

74 Republic of Kenya, National Climate Change Response Strategy, Government of Kenya, 2010.

75 Republic of Kenya, National Climate Change Action Plan 2013-2017, Government of Kenya, 2013, pp. 83-95.

76 Republic of Kenya, Finance-Investment Climate for Climate Investment, NCCAP, 2012, p.3. 
Table 1: Adaptation costings for a five year period as provided by sector agencies

\begin{tabular}{lll} 
Number & \multicolumn{1}{c|}{ Sector } & \multicolumn{1}{c}{ Estimated Cost billion Kshs for $\mathbf{5}$ years } \\
\hline ADAP-1 & Agriculture & 44.91 billion \\
\hline ADAP-2 & Livestock & 27.1 billion \\
\hline ADAP-3 & Water \& Sanitation & 278.76 billion \\
\hline ADAP-4 & Environment & 115 billion \\
\hline ADAP-5 & Infrastructure related to roads in ASALs & 107 billion \\
\hline ADAP-6 & Sustainable livelihoods related to ASALs & 59 billion \\
\hline ADAP-7 & Energy Infrastructure & 5.3 billion \\
\hline ADAP-8 & Tourism & 1.3 billion \\
\hline Total Kshs for next five years & Ksh $\mathbf{6 3 8}$ billion \\
\hline Total USD equivalent for five years & USD 7.5 billion \\
\hline
\end{tabular}

Table 2: Projected investment costs for priority mitigation actions

\begin{tabular}{l|l|l} 
Number & \multicolumn{1}{c|}{ Action } & \multicolumn{1}{c}{\begin{tabular}{c}
\multicolumn{1}{c}{ Estimated Cost Ksh to } \\
2030
\end{tabular}} \\
\hline MITI-1 & Restoration of Forests on Degraded Lands & $186-290$ billion \\
\hline MITI-2 & Geothermal & $877-1115$ billion \\
\hline MITI-3 & Reforestation of Degraded Forests & $48-61$ billion \\
\hline MITI-4 & Improved Cookstoves and LPG Cookstoves & 20 billion \\
\hline MITI-5 & Agroforestry & $70-117$ billion \\
\hline MITI-6 & Bus Rapid Transit and Light Rail Corridors & 170 billion \\
\hline MITI-7 & Development of GHG inventory and improvement of emissions & 42 million \\
& data & \\
\hline MITI-8 & Measuring, reporting on \& monitoring forestry emissions \& sinks & 624 million \\
\hline MITI-9 & Mainstreaming of low-carbon development options into planning & 21 million \\
\hline Total Cost & $\mathbf{1 3 7 1 - 1 7 7 3 ~ b i l l i o n ~ K s h ~}$ \\
\hline Total Ksh for next five years (USD 4596-5815 million equivalent) & $\mathbf{3 9 1 - 4 9 5}$ billion Ksh \\
\hline Total USD Equivalent to $\mathbf{2 0 3 0}$ & $\mathbf{1 6 - 2 2}$ billion USD \\
\hline
\end{tabular}


Under the Environmental Management and Coordination Act, any person who is a project proponent must apply for an environmental impact assessment (EIA) licence before financing or causing to be financed any undertaking specified in the Second Schedule to the Act.77 Projects that require an EIA licence under the Act include those relating to urban development, transportation, dams, mining, agriculture, manufacturing and processing industries and electrical infrastructure. Most Kenyan banks are involved in the financing of such projects. (See Figure 7) Because of the significance and central role of an EIA licence in ensuring sustainable development and sound environmental management in Kenya, ${ }^{78}$ there will be need to reassess how the tool can be used more effectively to realize sustainable finance.

77 See sections 58-67, Environmental Management and Coordination Act, Act No. 8 of 1999.

78 lbid, section 63.
As already indicated formal law is not the only governance framework in society. Some religious laws are also being used in implementing sustainability. Islamic banking which is compliant with Sharia law, prohibits the charging of interest on money lent, ${ }^{79}$ thus curbing the exploitation of borrowers. It also focuses on risk sharing, social justice and promotion of economic welfare. It also does not support ventures dealing in alcohol, pornography, pork and weapons. ${ }^{80}$ Some Islamic financial products such as ijara and sukuk give no guaranteed return and thus make all the parties to the instruments to aim at their long-term economic success. ${ }^{81}$ Sharia banking illustrates that it is indeed possible to adopt sustainable finance in spite of the law to realize environmental and social goals.

79 T. Sprangler, "Could Principles of Islamic Finance Feed into a Sustainable Economic System?" The Guardian, 18 0 ctober 2013.

80 Ibid.

81 A. Alawode, "Can Islamic Finance Spur Inclusive Growth and Sustainable Development?" LD Bank, 30 May 2013.

\section{Figure 7: Sectoral Distribution of Loans by Kenyan Banks (March 2014 and June 2014)}

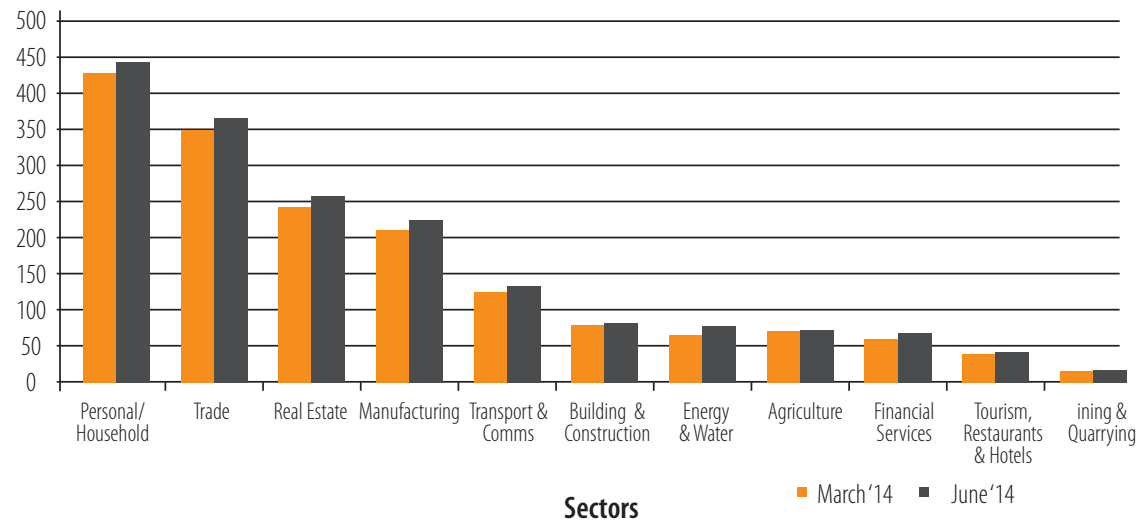




\subsection{Approaches in Implementing Sustainable Banking}

The implementation, monitoring and enforcement of sustainable development principles remain a challenge. The two main approaches to monitoring, implementation and enforcement are the command and control model and the voluntary approach. Each approach has its own salient advantages and disadvantages. The command and control model entails government or government agencies setting guidelines and standards and failure to comply with the guidelines attracts sanctions. ${ }^{82}$ Sanctions include cancellation or denial of licenses, imposition of fines or cancelation of projects.

The main advantages of a command and control model are that the guidelines are certain, their obedience is mandatory and a high compliance rate is possible since they are backed by sanctions. Moreover, government agencies can give incentives for compliance and ensure acceptance and implementation. However, the command and control model has some disadvantages. First, lack of adequate capacity can reduce its effectiveness in implementing sustainable finance. Second, government agencies may be subject to regulatory capture, a situation where the regulator protects banks from regulation.

82 C.L.C Migiro, "Cleaner Production Technologies and Industrialization for a Sustainable Environment" in UNEP, Industries and Enforcement of Environmental Law in Africa: Industry Experts Review Environmental Practice, p.84.
Further, non-compliant banks may corrupt or influence the regulator, leading to poor or lackluster implementation of the guidelines. ${ }^{83}$

The voluntary approach occurs when banks adopt and implement sustainable banking principles on their own initiative. The main advantage of the voluntary approach is that banks are likely to comply with guidelines adopted voluntarily. Moreover, it saves tax payers money in setting and implementing sustainable banking standards and guidelines. Further, self-regulation can complement government initiatives and therefore ensure greater compliance. However, voluntary approach has its own challenges. First, it may lead to unfair competition. Amalric asserts that since the principles are voluntary, some banks are unlikely to adopt them due to lack of sanctions. ${ }^{84}$ This is one of the main weaknesses of voluntary codes. It can therefore create unfair competition, where some banks would be incurring compliance costs, while others avoid those costs in a naked run for profits. Moreover, since there are no sanctions, banks can withdraw from the principles at whim.

Second, a voluntary approach is very uncertain. Often, the standards are ambiguous, loose and differ from organization to organization. Similarly, the enforcement mechanisms are weak and disjointed

83 lbid.

84 F. Amalric, "The Equator principles: A Step towards Sustainability?" Center for Corporate Responsibility Sustainability Working Paper Series, No. $1 / 05,2005$, p.1. 
since compliance depends on industry discipline, sustained campaigning by NGOs and peer pressure. ${ }^{85}$ There is also a problem of free riding, where some institutions benefit from the adoption of industrywide guidelines without actually taking steps to adopt those guidelines. Likewise, some banks subscribing to sustainable principles may only adopt them formally without implementation. For instance, in 2009, the United Nations Principles of Responsible Investments (UNPRI) announced the removal of six signatories who had voluntarily adopted but failed to implement the six principles of responsible investment. ${ }^{86}$

A hybrid of the two approaches appears to be the more appropriate model in integrating sustainability as it can ameliorate the salient weaknesses present in each. In Nigeria, a blend of both approaches has been adopted ${ }^{87} \mathrm{~A}$ committee consisting of representatives from the Central Bank of Nigeria, banking industry regulators, associations and banks has formulated the sustainable banking principles, guidance notes, and sustainable banking principles. The enforcement of the principles is vested on the Central Bank. The Bank requires regular reports on implementation and compliance. This is the command control aspect. The voluntary aspect requires individual banks to adopt the principles by incorporating environmental and

85 B.J. Richardson, "Africa: from object to agent of socially responsible investment," in F.N. Botchway (ed), Natural Resource Investment and Africa's Development, (Edward Elgar Publishing, 2011), p.247.

86 Ibid, p.272.

87 Central Bank of Nigeria, "Implementation of sustainable Banking Principles by Banks, Discount Houses and Development Finance Institutions" Circular FPR/DIR/IIR/GEN/01/33, September 2012. social risks appraisal in their management systems. In addition, the Central Bank offers incentives to banks and related institutions to ensure compliance with the principles.

There is need to put in place systems to measure, to monitor impacts and outcomes and to integrate findings for continuous improvement. There are different tools that can be employed to measure trends towards sustainability including; sustainability impact assessments; regulatory impact assessments, poverty impact assessments, environmental impact assessments and strategic environmental assessments. $^{88}$ A sustainability impact assessment assesses the three pillars of sustainability including cross-cutting, intangibleandlong-term considerations. It also assesses the likely economic, social and environmental effects of policies, strategies, plans and programmes before they are formulated making it the preferred tool in measuring sustainability. ${ }^{89}$ It is a holistic approach, unlike the regulatory impact assessments, or environmental impact assessments which address different aspects of sustainable development separately. To ensure transparency and to demonstrate corporate responsibility, there is need for a harmonized and effective reporting mechanism. Such a mechanism would allow banks to report about their business activities and operations and their social and environmental impacts.

\footnotetext{
88 lbid, p.109.

89 OECD, Guidance on Sustainability Impact Assessment, Sustainability Impact Assessment: An Introduction, 2010, available http://www. oecd.org/greengrowth/48305527.pdf, accessed on 12/08/ 2014.
} 


\subsection{Equator Principles and Sustainable Banking}

Leading banks, in cooperation with the International Finance Corporation (IFC) adopted the Equator Principles in 2003 to ensure that they appraised the environmental and social risks of projects they financed. Initially, the Principles required all projects above US $\$ 50$ million to be screened for environmental and social impacts. On revision in 2006, the amount was reduced to US\$10 million. The Equator Principles Finance Institutions (EPFI) categorizes projects into group $A, B$, and $C$ according to the $\mathbb{F C}$ standards. ${ }^{90}$ Category A projects are those with unprecedented impacts on the society and environment. For these projects, a bank must do another environmental assessment before extending credit and after ensuring that they are safe. Category B projects are less severe in consequence compared to category $A$, but still pose negative effects to wetlands, forests, human population and the environment. Category $B$ projects, like category A, must undergo environmental assessment before lending is authorized. Category $C$ projects are less severe in impacts and need not go through environmental assessment before financing.

EP Financial institutions are to engage local communities in constructive consultation processes and carry out social risk impact assessments to identify

90 F. Amalric, "The Equator principles: A Step towards Sustainability?" Center for Corporate Responsibility Sustainability Working Paper Series, Op. cit, p. 2. the significant impacts of projects on communities. Banks are to ensure that their clients tailor their consultation process to the risks and impacts of the project, the project's phase of development, the language preferences of the affected communities, their decision-making processes and the needs of disadvantaged and vulnerable groups. An Independent Environmental and Social Consultant is supposed to do an independent review for projects posing potential high risks including those with adverse impacts on indigenous peoples, those with negative impacts on critical habitats, those that have impacts on cultural heritage sites and those that result in large-scale resettlement. ${ }^{91}$ In relation to reporting, banks are supposed to establish appropriate mechanisms for reporting on the financial transactions they have financed annually. Appropriate reports are to be generated and made public. This makes banks to be socially responsible.

Membership to the Equator Principles has increased from initial ten banks to eighty members as at $2014 .{ }^{92}$ The first African bank to become an EPFI was Ned Bank of South Africa. As at 2014, African banks that are EPFIs signatories include Access Bank of Nigeria, Arab African International Bank of Egypt, BMCE Bank of Morocco, Ecobank of Togo, Fidelity Bank of Nigeria, First Rand of South Africa, Mauritius Commercial Bank Limited, Ned Bank of South Africa, and Standard Bank

91 lbid.

92 Available at http://www.equator-principles.com, accessed on 29/10/2014. 
of South Africa. ${ }^{93}$ No Kenyan incorporated bank has adopted the Equator Principles. Nonetheless, EPFls incorporated elsewhere have established branches, franchises and representative offices in Kenya. ${ }^{94}$ These banks include Barclays, Standard Chartered, Citi, Ecobank and Standard Bank through acquisition of Stanbic bank.

However, being voluntary codes, the implementation of the Principles faces numerous enforcement challenges. Some EPFls have provided financial lending to environmentally and socially controversial projects. For instance in Africa, Ned Bank and Standard Bank of South Africa financed the Kayelekera uranium mines yet no consultation was done with local communities on the project's deleterious water pollution. ${ }^{95}$ Globally, EPFI institutions including Citi, Societe Agricole, ING, West LB, and ABN AMRO were implicated in the financing of the Baku-TbilisiCeyhan (BTC) oil pipeline, whose environmental and social safety has been questioned by NGOs. ${ }^{96} \mathrm{NGO}$ 's believe that the banks financed these projects in

93 Ibid.

94 J. Osoro, Sustainable Finance Initiatives and banking in Kenya: The Inevitable or the Good-to-consider? Available at http://www.kba. co.ke/sfi/img/Sustainable\%20Finance\%20and\%20Banking\%20 in\%20Kenya\%20commentary\%20by\%20Jared\%200soro.pdf, accessed on 28/09/2014.

95 B.J. Richardson, "Africa: from object to agent of socially responsible investment," in F.N. Botchway (ed), Natural Resource Investment and Africa's Development, Op. cit, p. 276.

96 P. Bosshard, International Rivers Network, "An NGO Perspective on the Equator Principles," Proceedings of DPP Workshop on Financing Dams and Sustainable Development, held on 22-23 April,2004 in London. contravention of IFC standards and policies. ${ }^{97}$ The other criticism against the Equator Principles is that their coverage is too limited as it is determined by the types of projects, transactions and the lenders to whom they apply. It is argued that the Principles apply only to lenders who have adopted them, and who supply "project financing" of capital costs exceeding $\$ 50$ million. It is urged further that they do not define the transactions and projects to which they apply, and are subjective in determining whether more than the "satisfaction" of the signatories is required to demonstrate compliance. ${ }^{98}$

\subsection{Sustainability and African Countries}

The sustainability agenda in Africa has for a long time been driven by outsiders, such that Africa is often regarded as an object and not an agent of sustainability. ${ }^{99}$ Most of the large-scale projects in African have been financed by international financiers, including the Bretton Woods institutions. The challenge to outsiders, who champion sustainability in Africa, has been the identification of the scope, needs and agenda in Africa. ${ }^{100}$ Whereas most developed countries put emphasis on environmental

\section{7 lbid.}

98 R.F. Lawrence \& W.L. Thomas, "The Equator Principles and Project Finance: Sustainability in Practice?" Natural Resources \& Environment, Vol. 19, №. 2 (Fall 2004), pp. 20-26.

99 B.J. Richardson, "Africa: from object to agent of socially responsible investment," in F.N. Botchway (ed), Natural Resource Investment and Africa's Development, Op. cit, p. 247.

100 lbid. 
sustainability and focus on areas such as mitigation of climate change, reduction of emissions, regulation of genetic modified organisms, and exploitation of natural resources, ${ }^{101}$ in Africa sustainability has far greater economic and social undertones. In the African context, sustainability would require one to address matters of access to health services, education, clean water, reduction of poverty, food security, economic growth, equal access to opportunities for women, marginalization of minorities and disadvantaged groups, and wildlife conservation. ${ }^{102}$ Thus, outsiders who intend to promote sustainability in Africa must determine the specific needs of the community through public participation to ensure effective uptake of the concept. ${ }^{103}$ This is necessary considering that a number of banks in Kenya are owned by foreigners.

In recent times, African participants have become agents in sustainability as illustrated by South Africa and Nigeria. The sustainability projects are now based on local needs. A good example of Africa's agency in sustainability is the establishment of microfinance institutions and support for small and medium enterprises in Kenya. Microfinance institutions are helping in poverty alleviation by financing and educating their clients in business operations. In the same vein, the South African Bankers Association has focused efforts in matters

101 Ibid; UNEP Finance Initiative, Sustainability Banking- Africa Report, (UNEP, Nairobi), p. 2.

102 lbid.

103 UNEP Finance Initiative, Sustainability Banking-Africa Report, p.8. relating to education, poverty alleviation, and provision of health, with greater emphasis on the ubuntu philosophy. ${ }^{104}$ Another approach used by African agents of sustainability is the creation of foundations most of which are donor funded and focusing on poverty reduction, scholarships, and women empowerment. ${ }^{105}$ Banks therefore, have an opportunity to tailor their sustainability initiatives so as to address the most pressing and urgent needs in the African continent.

\subsubsection{Sustainable Finance Initiative by the Kenya Bankers Association ${ }^{106}$}

Currently, commercial banks are working on sustainability principles that will guide them in balancing their immediate business goals with the economy's future priorities and socio-economic concerns. This process began in September 2013, and is coordinated by the Kenya Bankers Association with the support of UNEP Finance Initiative (UNEP FI), the Netherlands Development Finance Company (FMO), German Investment Corporation (DEG) and the International Finance Corporation (IFC). The initiative will be guided by the Sustainable Finance Initiative (SFI) Working Group consisting of the KBA Secretariat

104 lbid, 263.

105 See for example the Equity Group Foundation with a huge percentage of its funding coming from donors.

106 Kenya Bankers Association, CEO Round table on Sustainable Finance Initiative, available at http://www.kba.co.ke/sfi/img/KBA CEO\%20 Roundtable\%20reportabbreviated\%20FINAL\%20as\%20at\%20 28\%200ct\%202013.pdf, accessed on 11/12/2014. 
and 12 banks. ${ }^{107}$ The Working Group is tasked with developing recommendations, including proposals on capacity building and development of Sustainable Finance Guiding Principles for the East African context. Drawing from global best practices, ${ }^{108}$ the SFI seeks to cover the economic, social and environmental dimensions of sustainability and to be responsive to individual banks' credit risk policies.

Already, the SFI Working Group has formed three teams to deal with Principles and procedures; capacity building; and the Green Economy. The SFI priorities are: comprehensive risk management; business practice, leadership and governance; and growth through inclusivity, innovation and technology. These priorities have been adopted as the focus thematic areas of the SFI. Five SFI Guiding Principles have been drafted and reviewed by the Working Group and the KBA Governing Council. These Principles are: financial returns versus economic viability; growth through inclusivity and innovation; managing and mitigating associated risks; resource scarcity and choice; and

107 These banks are Bank of Africa, Commercial Bank of Africa, Cooperative Bank of Kenya, Equity Bank, Gulf African Bank, Habib Bank, I \& M Bank, Jamii Bora Bank, KCB Group, NIC Bank, National Bank of Kenya and Standard Chartered Bank.

108 Some of the reviewed policy documents are: the IFC Sustainability Principles, UNEP FI Guidelines, UN Global Compact Principles, Equator Principles, Nigeria Sustainable Finance Principles \& Guidelines, African Development Bank Green Growth Initiative, Global Reporting Initiative Standards, ISO 26000:2010, Kyoto Protocol, ILO standards and China Green Credit Guidelines. business ethics and values. The Principles will inform financiers on how to optimize the balancing of their business goals with the economy's future priorities and socio-environmental concerns.

In capacity building, the aim is to have a financial sector in Kenya and East Africa Region that maintains and creates long-term value for banks, clients and society. This requires awareness raising, consensus building and changing mindsets; strengthening local advisory and academic institutions; and facilitating sustained collaboration and information dissemination. Capacity building also aims at leveling the playing field from a risk assessment and sustainability strategies development capacity perspective.

These efforts are necessary for the realization of long-term business success. They will also enhance innovation, competitiveness and the quality of bank credit. In addition, by integrating sustainability issues directly into their core business, banks will fundamentally contribute to the greening of business and industry, job creation, financial and social inclusion, and help society deal with challenges such as social inequity, climate change, resource scarcity and biodiversity loss. 


\section{Data Collection and Analysis}

oth primary and secondary data were collected. Primary data was

Dobtained in both written and oral form from nine (9) banks namely Equity Bank, Co-operative Bank, Barclays Bank Kenya Limited, Standard Chartered Bank Kenya, Eco-bank, National Bank of Kenya, Consolidated Bank, Chase Bank, and Family Bank. These banks were selected because of the initiatives they had initiated in sustainability and also to assess diversity and robustness of initiatives amongst local, foreign incorporated and banks with huge government shareholding.

A questionnaire with questions on the three main pillars of sustainability was administered to bank officers mostly in the corporate affairs, legal and marketing departments. Officers in these departments were chosen as they were expected to know the bank's initiatives towards sustainability. Secondary data was also obtained from Kenya Commercial Bank due to its robust sustainability initiatives. Secondary data was derived mostly from the official bank websites, annual reports, sustainability reports and newsletters. A letter introducing the researcher to the banks was granted by the Kenya Bankers Association.

Since this was a descriptive study, the collected data was qualitative and the content analysis technique was used to analyse data thematically and systematically. Responses were grouped as touching either on economic, social or environmental sustainability and analyzing them in the context of the research objectives. 


\section{Data Results}

A number of factors may affect the results of the study. First, sustainable banking is a novel idea in the Kenyan market. Capacity building is therefore necessary for officials to assess whether a bank is operating sustainably or not. In addition, most banks do not have policies on sustainability and very few banks were generating sustainability reports. Second, some answers may be false negatives since most banks in Kenya have not financed large-scale projects so as to answer questions on sustainability effectively. Third, there may be a danger of bias, where bank employees give positive and exaggerated information so as to improve the reputation of the bank. Despite these concerns on primary data, the data provided by banks was cross-checked with secondary sources.

\section{A Summary of Responses to the close-ended Questions}

\subsection{Environmental sustainability}

\begin{tabular}{|c|c|c|c|c|c|c|c|c|c|}
\hline Question & $\begin{array}{c}\text { Bank } \\
\text { A }\end{array}$ & $\begin{array}{c}\text { Bank } \\
\text { B }\end{array}$ & $\begin{array}{c}\text { Bank } \\
\text { C }\end{array}$ & $\begin{array}{c}\text { Bank } \\
\text { D }\end{array}$ & $\begin{array}{c}\text { Bank } \\
\text { E }\end{array}$ & $\begin{array}{c}\text { Bank } \\
\text { F }\end{array}$ & $\begin{array}{c}\text { Bank } \\
\text { G }\end{array}$ & $\begin{array}{c}\text { Bank } \\
\text { H }\end{array}$ & $\begin{array}{c}\text { Bank } \\
\text { I }\end{array}$ \\
\hline $\begin{array}{l}\text { 1. Does the bank have an environmental policy state- } \\
\text { ment? }\end{array}$ & Yes & Yes & Yes & Yes & Yes & No & No & Yes & No \\
\hline $\begin{array}{l}\text { 2. Does the bank produce sustainability/environmen- } \\
\text { tal reports based on its operations? }\end{array}$ & Yes & Yes & Yes & Yes & No & No & № & Yes & No \\
\hline $\begin{array}{l}\text { 3. Has the bank incorporated environmental consider- } \\
\text { ations into its decision-making process? }\end{array}$ & Yes & Yes & Yes & Yes & Yes & Yes & Yes & Yes & Yes \\
\hline $\begin{array}{l}\text { 4. Has the bank established categories of potential } \\
\text { environmental risks, which may result from its } \\
\text { client's activities? }\end{array}$ & Yes & Yes & Yes & Yes & Yes & No & Yes & Yes & No \\
\hline $\begin{array}{l}\text { 5. Before extending credit to a client, does the bank } \\
\text { carry out an environmental risk exposure survey? }\end{array}$ & Yes & Yes & Yes & Yes & Yes & No & No & Yes & Yes \\
\hline $\begin{array}{l}\text { 6. Has the bank ever refused to extend credit to a client } \\
\text { due to negative environmental impacts? }\end{array}$ & Yes & Yes & Yes & N/A & Yes & No & No & Yes & No \\
\hline $\begin{array}{l}\text { 7. Does the bank enquire that its clients comply with } \\
\text { environmental laws? }\end{array}$ & Yes & Yes & Yes & Yes & Yes & Yes & Yes & Yes & Yes \\
\hline
\end{tabular}




\subsection{Social Sustainability}

\begin{tabular}{|c|c|c|c|c|c|c|c|c|c|}
\hline Question & $\begin{array}{c}\text { Bank } \\
\text { A }\end{array}$ & $\begin{array}{c}\text { Bank } \\
\text { B }\end{array}$ & $\begin{array}{c}\text { Bank } \\
\text { C }\end{array}$ & $\begin{array}{c}\text { Bank } \\
\text { D }\end{array}$ & $\begin{array}{c}\text { Bank } \\
\text { E }\end{array}$ & $\begin{array}{c}\text { Bank } \\
\text { F }\end{array}$ & $\begin{array}{c}\text { Bank } \\
\text { G }\end{array}$ & $\begin{array}{c}\text { Bank } \\
\text { H }\end{array}$ & $\begin{array}{c}\text { Bank } \\
\text { I }\end{array}$ \\
\hline $\begin{array}{l}\text { 1. Does the bank train its employees on sustainable } \\
\text { operations? }\end{array}$ & Yes & Yes & Yes & Yes & Yes & Yes & Yes & Yes & Yes \\
\hline $\begin{array}{l}\text { 2. Has the bank shown concern for sustainability initia- } \\
\text { tives? }\end{array}$ & Yes & Yes & Yes & Yes & Yes & Yes & Yes & Yes & Yes \\
\hline $\begin{array}{l}\text { 3. Does the bank carry out social risk exposure survey } \\
\text { before extending credit? }\end{array}$ & Yes & Yes & Yes & Yes & Yes & Yes & Yes & Yes & Yes \\
\hline $\begin{array}{l}\text { 4. Are there projects financed by the bank that have led } \\
\text { to displacement of communities? }\end{array}$ & Yes & No & No & No & No & No & No & No & No \\
\hline $\begin{array}{l}\text { 5. Does the bank educate communities to be affected } \\
\text { by project financed by the bank? }\end{array}$ & Yes & Yes & Yes & No & No & No & No & Yes & No \\
\hline $\begin{array}{l}\text { 6. Has the bank established a financial model for mar- } \\
\text { ginalized groups? }\end{array}$ & Yes & Yes & Yes & Yes & Yes & Yes & Yes & Yes & Yes \\
\hline $\begin{array}{l}\text { 7. Has the bank categorized potential social risk from its } \\
\text { clients' project? }\end{array}$ & Yes & Yes & Yes & Yes & Yes & Yes & Yes & Yes & Yes \\
\hline
\end{tabular}

\subsection{Economic Sustainability}

\begin{tabular}{|c|c|c|c|c|c|c|c|c|c|c|}
\hline \multicolumn{2}{|c|}{ Question } & $\begin{array}{c}\text { Bank } \\
\text { A }\end{array}$ & $\begin{array}{c}\text { Bank } \\
\text { B }\end{array}$ & $\begin{array}{c}\text { Bank } \\
\text { C }\end{array}$ & $\begin{array}{c}\text { Bank } \\
\text { D }\end{array}$ & $\begin{array}{c}\text { Bank } \\
\text { E }\end{array}$ & $\begin{array}{c}\text { Bank } \\
\text { F }\end{array}$ & $\begin{array}{c}\text { Bank } \\
\text { G }\end{array}$ & $\begin{array}{c}\text { Bank } \\
\text { H }\end{array}$ & $\begin{array}{c}\text { Bank } \\
\text { I }\end{array}$ \\
\hline 1. & $\begin{array}{l}\text { Has the bank established programmes aligned } \\
\text { towards the protection of resource efficiency? }\end{array}$ & Yes & Yes & Yes & Yes & No & No & Yes & Yes & Yes \\
\hline 2. & $\begin{array}{l}\text { Has the bank embraced the use of ICT in its op- } \\
\text { eration? }\end{array}$ & Yes & Yes & Yes & Yes & Yes & Yes & Yes & Yes & Yes \\
\hline 3. & $\begin{array}{l}\text { Does the bank contribute to research in sustain- } \\
\text { able areas? }\end{array}$ & Yes & Yes & Yes & Yes & Yes & Yes & Yes & Yes & Yes \\
\hline 4. & $\begin{array}{l}\text { Does the bank support investment in sustainable } \\
\text { business opportunities? }\end{array}$ & Yes & Yes & Yes & Yes & Yes & Yes & Yes & Yes & Yes \\
\hline
\end{tabular}




\section{Data Analysis on the three Pillars of Sustainable Banking}

\subsection{Environmental sustainability}

II the banks under survey indicated that they had adopted initiatives
aimed at environmental sustainability. Some have adopted internal energy efficiency programmes to reduce negative environmental impacts such as switch-off campaigns, use of energy saving bulbs to conserve electricity, doing paperless banking, doing double sided photocopying to save on paper and providing dustbins in their ATMs.

In internal resource efficiency, Standard Chartered Bank Kenya Limited has identified energy, water and paper consumption as focus areas. It harvests rainwater, collects sewage for treatment and has waterless urinals. The bank monitors energy use using a Global Environmental Management System (GEMS) which is modeled on ISO 14001. The bank also has a greywater recycling system that allows it to save nearly 2 million litres of potable water every year.109 It has also invested in Information Retention Management Programme to reduce paper consumption and in audio and video conferencing facilities to minimize travel expenses. 110 Likewise, KCB has harnessed technology and is holding virtual meetings instead of face-to-face meetings to reduce its transport carbon footprint.111 On its part, Cooperative Bank is lowering its carbon footprint by installing air conditioning equipment with green gases; deploying inverters as power back up in ATM sites; using low noise level (below 50db) acoustic canopies in generators to reduce sound and noise pollution. 112

109 Available at http://reports.standardchartered.com/sustainability-review-2013/pdf/2013Sustainability_Review.pdf, accessed on 29/09/2014.

110 Standard Chartered Bank Kenya Limited, Annual Report, 2011, p.26.

111 KCB Group, Sustainability Report, 2013, p.26.

112 Cooperative Bank of Kenya, Sustainability Report, 2013, p.21. 
Some banks like Equity Bank have comprehensive environmental and social impact policies. These policies are audited internally to ensure effectiveness. Similarly, Barclays Bank Kenya has an Environmental Management System (EMS) frameworkfor monitoring and managing the impact of its operations on the environment..$^{113}$ In addition, Equity Bank, Chase Bank and Standard Chartered Banks indicated that they have adopted the International Finance Corporation performance standards to ensure environmental sustainability. ${ }^{114}$

Most banks stated that they were engaging in environmental conservation and protection efforts in the country. For instance, Equity bank through its Foundation is a founding trustee of the'Save the Mau Initiative' while both Barclays Bank and National Bank of Kenya are involved in tree planting at the Karura Forest and are Friends of the Karura Forest Project. KCB has also supported the rehabilitation of the Mau Likia block by planting tree seedlings in partnership with local communities..$^{115}$ Cooperative Bank is involved in the rehabilitation of the Njoro River and tree planting along the river. Banks are also organizing conferences and workshops to increase awareness on social and environmental sustainability. ${ }^{116}$

113 Available at http://www.barclays.co.ke/citizenship/index.html accessed on 01/08/14.

114 See also Equity Group Foundation, Annual Report (Equity Group Foundation, 2012); Standard Chartered Bank Kenya Limited, Annual Report, 2011; Chase Bank, Annual Report, 2012.

115 KCB Group, Sustainability Report, 2013.

116 Chase Bank, Annual Report, 2012; see also Co-operative Bank, Sustainability Report, 2013.
Some banks are financing green initiatives to promote environmental sustainability. A good example, is Cooperative Bank which has financed green projects such as the installation of solar panels, biomass and wind energy projects. As a result of its efforts, the Bank was recently voted the best local participating bank in renewable energy and energy efficiency in the 2013 Energy Management Awards. ${ }^{117}$ Through the Equity Group Foundation, Equity Bank is supporting smallscale farmers to invest in biogas technology to reduce dependence on wood fuel and mitigate the adverse effects of climate change and reduce total fuel costs. ${ }^{118}$

Banks are concerned with the environmental risks posed by their activities and some have come up with categories of these risks. However, the categorization of risks is not harmonized and is haphazard. Some are classifying environmental risks as high, medium or low. Others classify environmental risks as compliance risks, market risks, pollution, economic viability or social risks. Across the board, the manner and procedure of assessing environmental risks is haphazard and depends on individual bank's policies. The disparities in the manner and methods of categorizing risks and carrying out environmental exposure survey puts into question their effectiveness. This creates the need for the formulation of some guidelines.

All the nine banks under survey indicated that they checked compliance with environmental laws and

117 Ibid, Co-operative Bank, Sustainability Report, 2013.

118 Equity Group Foundation, Annual Report, 2012, p. 43. 
regulations before extending credit. (See also Figure 8) Most banks employ the EIA process to assess compliance with environmental laws and regulations. Whereas the EIA process can be a good tool for ensuring social and environmental sustainability, its use in practice faces numerous challenges. First, the contractor/developer plays a major role in the EIA process, and as such the primary objective of the ElA is not truthfully and faithfully fulfilled. ${ }^{119}$ Second, while National Environment Management Authority (NEMA) is the only body mandated to issue EIA licenses in Kenya, ${ }_{1}^{120}$ the actual environmental impact study and report on the basis of which the licence is issued are prepared by firms and experts licensed by NEMA. ${ }^{121}$ Thirdly, the EIA process is usually flawed due to non-compliance with regulations, lack of public participation, inadequate use of monitoring information and low capacity amongst NEMA officials. ${ }^{122}$ An EIA licence is therefore not a true indicator of whether a client has complied with environmental laws and regulations or not. Nonetheless, five of the nine banks interviewed reported that they had denied credit to their customers based on the negative impacts their projects could have on the environment.

119 Nairobi-Thika Highway Improvement Project-An Environmental Assessment available at csud.ei.columbia.edu/files/2013/10/ Irandu_reportFinal.pdf, accessed on 11/12/2014.

120 See Sections 58-67. Environmental Management and Coordination Act No. 8 of 1999.

121 lbid, Section 58(5).

122 0.N. Omondi, 'Improving Kenya's Environmental Impact Assessment and Strategic Environmental Assessment for Sustainable Development,' (Msc. Thesis, UNESCO-IHE, Institute for Water Education), p.13.
The Equator Principles Financial institutions surveyed in this study carried out environmental and social screening of projects according to the International Finance Corporation guidelines. They depicted a deeper appreciation of sustainability and had relatively more robust sustainability initiatives. They also carried out detailed social and environmental screening before extending credit to their customers. For example, Standard Chartered Bank Kenya Limited a member of the Climate Group, UNEP FI and support to key policy statements such as Copenhagen Communiqué, ${ }^{123}$ which shows strong commitment to environmental sustainability.

\subsection{Social sustainability}

The main areas of social sustainability being supported by banks are health, agriculture, education, innovation and entrepreneurship. Most banks are supporting education in secondary, university and at post-graduate levels. For instance, Equity Bank through the Wings to Fly scholarship programme has provided scholarship opportunities to over 8403 scholars as at 2014.124 This has enabled many needy students to access higher education institutions both in the country and abroad. Co-operative Bank through the Co-operative Bank Foundation is currently paying school fees for 2,293 secondary students, 84 university students and 4 cooperative college students totaling to over Ksh. $87.5 \mathrm{M} .{ }^{125}$ Chase Bank is also offering

123 Standard Chartered Bank Kenya Limited, Annual Report, 2011, p. 26.

124 A presentation on Equity Group Foundation, 2014. This document is in the authors file.

125 Co-operative Bank, Sustainability Report, 2013, pp.14-16. 
scholarships and bursaries to needy students through the Chase Bank Foundation. ${ }^{126}$ The beneficiaries of education scholarships have been able to get jobs after school thus improving their lives and those of their families.

In health matters, Kenyan banks have initiated various programmes aimed at curbing preventive and curative health problems. Support is largely directed towards supporting hospitals and clinics in acquiring modern equipment and facilities. For example, in 2013, KCB reports having invested Kshs. 33 million in hospitals and clinics to acquire equipments for kidney transplants, heart operations and screening. ${ }^{127}$ Likewise in 2012, the National Bank of Kenya donated six Dialysis machines to Coast General Hospital, Rift Valley Provincial General Hospital and Moi Teaching and Referral Hospital at a total cost of Sh. 10 million. ${ }^{128}$ The other banks have programmes sponsoring hospitals in curbing different ailments. One such bank is Standard Chartered Bank which has a programme 'Seeing is Believing' where it sponsors hospitals in a bid to eradicate blindness caused by cataract, glaucoma and trauma related surgeries in children and the elderly. In addition, the Bank organizes the Standard Chartered Nairobi Marathon to raise money to eradicate cases of avoidable blindness in Kenya. ${ }^{129}$ Chase Bank organized a 10 kilometre charity walk

126 Chase Bank, Annual Report, 2012.

127 KCB Group, Sustainability Report, 2013, p.24.

128 National Bank of Kenya, Annual Report, 2012, pp.23-24.

129 Standard Chartered Bank Kenya Limited, Annual Report, 2011, pp, 27-30. on 9th February 2013, in the Ngong Road Forest Sanctuary to raise funds to help reduce maternal mortality in Kenya by $25 \% .{ }^{130}$

Cooperative Bank is leading the pack in supporting agri-business by providing financial services to over 90\% of the country's cooperatives most of which are involved in agriculture. ${ }^{131}$ Most of the other banks have extended finance to small-scale entrepreneurs to build capacity and increase agricultural productivity. In 2013, KCB invested Kshs. 34 million to help over 600 small-scale entrepreneurs in capacity building and purchase of production equipment to smallscale enterprises. ${ }^{132}$ Banks are also financing irrigation projects in a paradigmatic shift from rain-fed agriculture to sustainable food production. ${ }^{133}$

Most of the banks under survey indicated that they carry out social screening before extending credit. Social screening practices range from checking compliance with the IFC performance standards, use of exclusion lists, site visits, checking compliance with EIA licence, due diligence tests, monitoring of portfolio, evaluation by board of directors, ${ }^{134}$ and carrying out

130 Available at http://www.chasebankkenya.co.ke/sites/default/files/ uploads/Chasebank\%20Annual\%20Report\%202012.pdf, accessed on $07 / 08 / 2014$.

131 Co-operative Bank, Sustainability Report, 2013, p.13.

132 KCB Group, Sustainability Report, 2013, p.24.

133 Banks financing such projects include Cooperative Bank, Equity Bank and Kenya Commercial Bank.

134 For in Equity Bank and National Bank of Kenya, the Board of Directors has the overall responsibility for the establishment and oversight of the Bank's risk management framework. 
social impact survey of projects. (See also Figure 8) One of the banks indicated that for projects in excess of Kshs. 20 million it has to conduct a social impact evaluation. In addition, one of the banks under survey stated that it had refused to extend credit to a company whose activities were harmful to the environment and the contiguous communities. Banks are also carrying out financial literacy programmes to train women and youth on good financial management practices that can help them transform their livelihoods. ${ }^{135}$

135 Equity Bank, through the Equity Group Foundation launched the Financial Knowledge for Africa (FiKA) initiative in 2010. Under the
Some of the banks under survey have carried out educational awareness and advised local communities about intended projects. For example, Equity Bank carried out an awareness programme with Baringo residents on the impacts of the proposed biomass power plant using the Mathenge plant. Similarly, Co-operative Bank has in partnership with Egerton University, educated local residents on the Njoro River Rehabilitation Project. ${ }^{136}$

programme over 1 million trainees had been trained by end of 2013. 136 Co-operative Bank, Sustainability report, 2013, p. 23-24.

\section{Figure 8: Number of Banks with the following elements of an Environmental and Social Risk Management System}

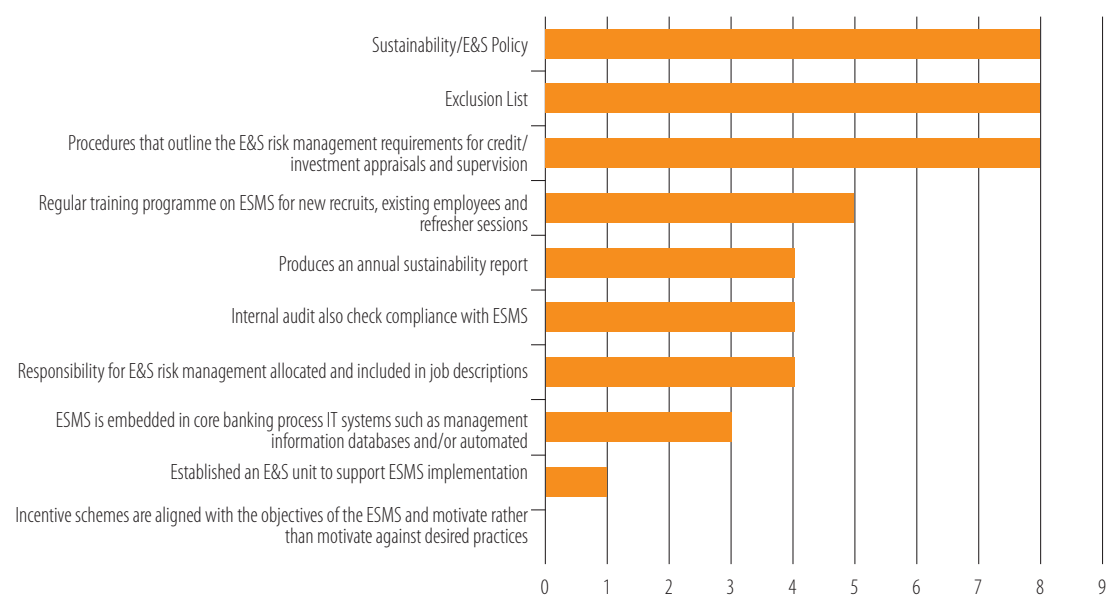


Kenyan banks are also offering products and services for disadvantaged groups in society, such as youth, women, students and small, medium and micro enterprises. For example, Chase Bank has a department dealing with women welfare, ${ }^{137}$ and is supporting maternal women through the Chase Bank Foundation. Likewise, Equity Bank, Consolidated Bank, Barclays Bank, National Bank, Co-operative Bank, Standard Chartered Bank, KCB and Eco-Bank have special products and services for women and women groups, youth, students and SMEs. Standard Chartered Bank has introduced, Standard Chartered Sadiq, an Islamic product aimed at enhancing financial access to the untapped segment in the market. ${ }^{138}$ KCB has also introduced Islamic banking to engender financial inclusion. ${ }^{139}$ Moreover, National Bank of Kenya has a National Amanah account, which is a Shariah compliant account and where no interest is paid or charges levied; and the National Amanah financing facility, which is a Shariah compliant asset financing product. ${ }^{140}$

Banks are also providing financial services to small micro-enterprises (SMEs) enabling them to save for future investments, increase their asset base and

137 See also Available at http://www.chasebankkenya.co.ke/sites/ default/files/uploads/Chasebank\%20Annual\%20Report\%202012. pdf, accessed on 07/08/2014.

138 Standard Chartered PLC, Sustainability Review 2013, p. 13.

139 KCB Group, Sustainability Report, 2013.

140 National Bank of Kenya, Annual Report \& Financial Statements, 2012, p.84. minimize external shocks to their businesses. ${ }^{141}$ Banks are also offering SME loans to assist business people develop their businesses. ${ }^{142}$ Equity Bank has an SMEBusiness Loan which is available to SMEs operating in the transport, trade and commerce, construction, manufacturing, education, health \& other services sector; a development Loan which is extended to SMEs wishing to expand their businesses or to acquire business assets; and a 'Biashara Imara' loan which is a working capital facility extended to micro clients with no conventional collateral. ${ }^{143}$

Moreover, some banks have taken up agency banking which has enabled many Kenyans to access banking services within a short distance from their homes or businesses. Agency banking allows entities approved by the Central Bank to enter into contracts with banks to provide banking services on behalf of those banks. ${ }^{144}$ Bank agents are therefore representatives of the bank at grassroots level. ${ }^{145}$ Although agency banking was introduced in 2010, as at $30^{\text {th }}$ June 2014, 15 commercial banks had contracted 26,750 active agents who were facilitating over 106.1 million transactions valued at Ksh. 571.5 billion. ${ }^{146}$ Agency

141 Co-operative Bank, Sustainability Report, 2013, p.12.

142 All the banks under survey had business loans targeted at small and micro-enterprises.

143 Equity Bank Group, Annual Report, 2013, p.116.

144 Guideline 1.4, Central Bank of Kenya, Guidelines on Agent Banking, (BK/PG/15.

145 Ibid, Guideline 2.1.1.

146 CBK Supervision Reports, available at https://www.centralbank. go.ke/images/docs/Bank\%20Supervision\%20Reports/Quarterly\%20 Performance\%20Reports/Q2_of_2014_Banking_Sector_ 
banking has a number of advantages. First, it brings about financial inclusion to parts of the population that would otherwise be excluded. Second, it enables banks to avoid making huge investments in establishing branches in areas that operation costs would exceed possible gains. Thirdly, the agency banking model has become a source of employment for many youth in rural areas. Agency banking is thus a form of social and economic sustainability both for the banks and for the target markets. In 2011, KCB pioneered Agent banking and has since recruited over 7000 agents who are transacting an average of 10,000 transactions daily. ${ }^{147}$

Most banks under survey have programs aimed at employees and staff development. All the banks under survey indicated that they carry out training of employees on sustainability issues. Sustainable employee practices adopted by banks include employee training and career development; labour rights; offering employee benefits and sensitization on HIV/AIDs. Cooperative Bank has a HIV/AIDS policy under which the bank does not screen for HIV/AIDs during recruitment nor discriminate against HIV positive staff. ${ }^{148} \mathrm{KBA}$ is also in the process of building capacity amongst banks by training on sustainable finance.

Performance Developments.pdf, accessed on 10/1/2015.

147 KCB Group, Sustainability Report, 2013. Equity Bank, National Bank of Kenya and Cooperative Bank are also doing agency banking.

148 Co-operative Bank, Sustainability Report, 2013, p.19.

\subsection{Economic Sustainability}

Banks are streamlining their operations and activities to ensure optimal performance and efficient resource use. For instance, most of the banks under survey indicated that they are using ICT and had automated banking operations and activities by having either mobile banking, online banking or automated teller machines (ATMs). By using ICT based platforms, banks are saving on time and cost and have become more efficient and effective in serving their customers. Additionally, it increases financial inclusion since people in remote areas can do most of their banking through the phone, especially with almost countrywide presence of mobile money transfer. A mobile banking survey in Kenya found out that mobile banking increases financial deepening especially in the rural areas since $71 \%$ of respondents in rural areas were more likely to use mobile banking while only $57 \%$ of respondents in urban areas would do the same. ${ }^{149}$ Banks with mobile banking platforms include Co-operative Bank, Kenya Commercial Bank, Standard Charted Bank, Barclays Bank and Equity Bank. ${ }^{150}$ For example, KCB has mobile-phone based banking (KCB Connect introduced in 2006 and KCB Mobi Bank in 2012) and internet banking (KCB i-Bank introduced in 2011). Most banks in the country have ATMs and this helps save on costs involved in establishing branches,

149 Kenya Bankers Association, Centre for Research on Financial Markets and Policy, The Mobile Banking Survey (Nairobi: Kenya Bankers Association, Jan 2014), p.16.

150 Ibid, p.7-8. 
and reducing carbon footprint. Although, automation is sustainable economically, environmentally and socially, in the end it results in reduction in demand for human personnel.

Banks are also adopting financial risk management guidelines to identify the risks they are likely to fall into and to minimize financial loss. For example, Equity Bank $k^{151}$ and National Bank of Kenya ${ }^{152}$ have categorized financial risks into credit, ${ }^{153}$ liquidity ${ }^{154}$ and market risks, 155 and have risk management policies to identify, analyse, set appropriate risk limits and controls, and to monitor risks and adherence to limits. KCB classifies risks into information, market, compliance and reputational risks. The bank manages information risks by continually renewing its IT security policy, monitoring operations and having stringent personal information protection. It manages market risks by carrying out daily monitoring before changing investment profiles and by effectively managing liquidity and solvency ratios. The bank manages reputational risks by, inter alia, issuing identification through internal/external incidents, outsourcing media monitors for print, electronic

151 Equity Bank Group, Annual Report, 2013, pp.73-84.

152 National Bank of Kenya, Annual Report \& Financial Statements, 2012, pp. 63-77.

153 This refers to risk of financial loss if a customer fails to meet its contractual obligations and arises principally from loans and advances to customers, other banks and investment securities.

154 Liquidity risk refers to risks that the bank will encounter difficulty in meeting obligations from its financial liabilities.

155 Market risks are those risks that changes in market prices will affect the bank's income or value of its holdings of financial investments. and social media, resolution of raised issues and proper senior management oversight through the committee. ${ }^{156} \mathrm{It}$ deals with compliance risks by, inter alia, identifying changes in regulatory frameworks, gap analysis, enhancing internal policy to ensure compliance and continuous compliance training for staff. The bank is also working on its geographical expansion, adding more branches; introducing new product portfolios such as bancassurance, investment banking and realization of revenues from maturing long term investments. Operational efficiency is done through staff restructuring, automation of processes and strategic divestments from non-core business assets and move towards leasing agreements. ${ }^{157}$

Banks are also contributing to economic growth through credit extension and project finance. For instance, it is reported that in the first half of 2012, the banking industry committed Kshs. 1550.52 billion in domestic credit. ${ }^{158}$ The sector is also contributing to overall economic growth by paying taxes to the government. In December 2013, the banking sector recorded a pre-tax profit of Ksh. 125.8 billion which was an increase of $16.6 \%$ from Ksh. 107.9 billion recorded in December 2012. ${ }^{159}$ In 2012, four of the banks under survey (KCB, Equity Bank, Barclays Bank Kenya Limited and Cooperative Bank) paid Kshs. 18.2

156 KCB Group, Sustainability Report, 2013, pp. 17-18.

157 lbid.

158 Kenya Bankers Association, Kenya Bankers Bulletin, Vol 3, 2013, p.10.

159 Central Bank of Kenya, Bank Supervision Annual Report 2013, Central Bank of Kenya, 2013, p. 32. 
billion in tax on their pre-tax profit. ${ }^{160}$ Corporate tax payable by banks is growing tremendously as the industry continues to record rising profits annually. Apart from corporate tax, banks also pay VAT, stamp duty and income tax annually. Tax paid to the government goes towards various social-economic programmes that contribute to the well-being of all Kenyans.

By providing banking services to millions of unbanked Kenyans, banks are essentially contributing to socioeconomic development of the country. Most banks have developed banking models that are cheap and that use low cost distribution channels such as ATMs, internet, mobile and agent banking. These products are affordable, simple and accessible for use by clients. It is now possible for clients especially SMEs to have access to financial services from banks. This enables clients to save for future investments, increase asset base and minimize external shocks to their businesses. ${ }^{161}$ Most of the banks under survey indicated that they had departments dealing with agri-business to finance and provide advisory support to farmers on the entire agriculture value chain. One of the most outstanding banks in supporting agri-business is Cooperative Bank, which is currently providing banking solutions to over $90 \%$ of the country's cooperatives. The bank

160 Available at http://www.technologybanker.com/breaking-news/ kenyas-top-4-banks-pay-sh182-billion-in-tax\#.VIfm CAEBg. accessed on 11/12/2014.

161 Co-operative Bank, Sustainability Report, 2013, p.12. has also established the Kenya Co-operative Coffee Exporters Ltd to help coffee farmers maximize return on their business and take greater control of the coffee value chain. ${ }^{162}$

\subsection{Research Findings}

Sustainability has become an issue of major concern for the banking industry in Kenya especially with the enactment of the Constitution of Kenya 2010. The Constitution requires development to be pursued sustainably by all including banks. However, the study finds that initiatives aimed at sustainable banking in Kenya are varied, diverse and uncoordinated. There have been no harmonised guidelines on how banks uniformly adopt sustainable finance practices; however, through KBA, efforts have begun to move banks towards sustainable development in their operations and activities. Most banks considered themselves to be carrying out their business sustainably, although most of their initiatives bordered on CSR. (See Figure below) Most of the banks under survey had robust CSR programmes. These programmes aimed at poverty alleviation, education, health, women empowerment, and related social initiatives that are likely to give banks competitive edge in the market.

162 lbid, p.13. 


\section{Figure 9: Self Rating of Performance on Sustainable Finance Themes}

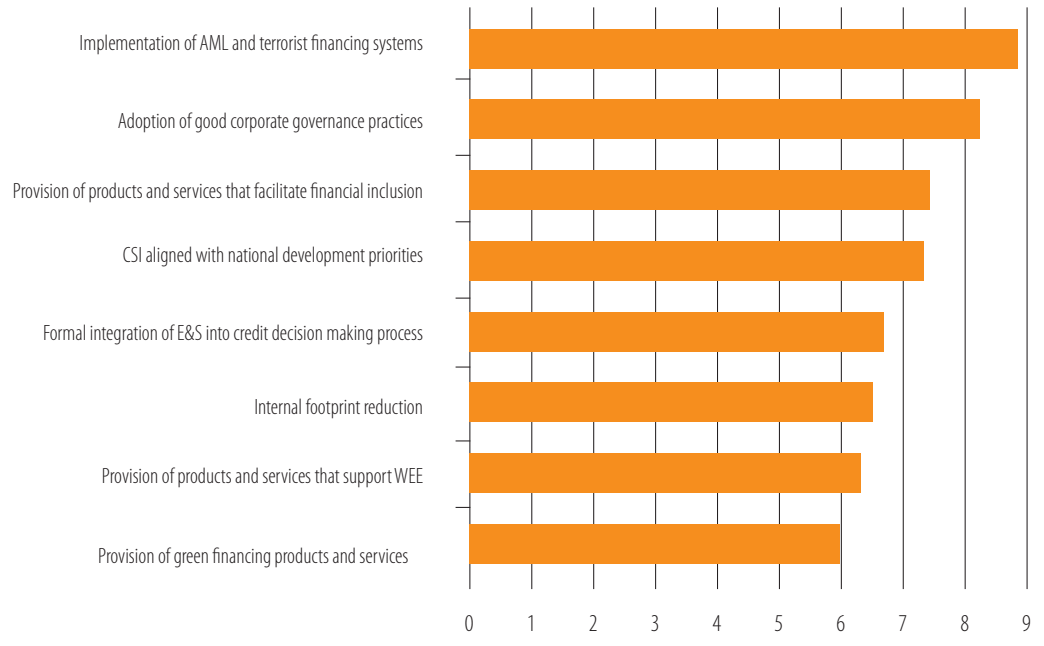

\section{Source: KBA SFI Needs Assessment Report, 2014.}

Banks that are incorporated abroad are carrying out their operations and activities in line with internationally recognized sustainable banking principles to which they have subscribed. Others have established foundations to carry out their initiatives towards the society and environment. Such foundations include the Equity Group Foundation, Kenya Commercial Bank Foundation, ${ }^{163}$ Cooperative Bank Foundation and the Chase Bank Foundation.

163 See generally KCB Foundation, available at http://ke.kcbbankgroup. com/foundation/, accessed on 29/09/2014.

However, the study found out that a large percentage of funding to some foundations came from donors and not the banks themselves. This raised questions about the sustainability of initiatives under those foundations. Some banks are also carrying out sustainability reporting in addition to the traditional release of a balance sheet, the profit and loss account, and the directors' report. ${ }^{164}$ Although, the efforts by banks are laudable, there is need for industry guidelines on sustainability considering that initiatives

164 Ibid. 
towards sustainability are varied. Moreover, reporting on sustainability is varied and is dependent on each banks policy. The study also shows that most banks irrespective of their size, origin and ownership have adopted initiatives that implement different aspects of sustainability. 


\section{Conclusion and Way Forward}

Custainable development is a constitutional value and principle of governance that all corporations must integrate in their operations and activities. In the banking sector, sustainability can be attained by adoption of sustainable banking. In Kenya therefore, sustainable banking is a legal and not a moral requirement. Its implementation requires going beyond CSR, which is mostly viewed as a philanthropic gesture meant at gaining competitive advantage in the market. It is therefore imperative for the banking sector to integrate sustainable banking and to develop sustainable finance guidelines, so as to comply with the law and for long term business success. The study finds sustainability initiatives among banks in Kenya are diverse, varied and uncoordinated. In that regard, the study makes the following recommendations:

First, there is need for industry-wide guidelines on sustainable banking. It is noteworthy that KBA is working towards developing capacity on sustainable finance amongst banks and in formulating sustainable finance principles. The study notes that in developing the sustainable banking guidelines, the relevant stakeholders including the Central Bank of Kenya, Kenya Banker's Association, Nairobi Securities Exchange, Capital Markets Authority banks and sustainability experts should be involved in the process. ${ }^{165}$ (See the relevant actors in Table 3 below, their role and levels of engagement)The guidelines should apply to all banks and cover all transactions and operations of banks. Moreover, there should be sector-specific principles applicable when lending to sectors such as agriculture, power, oil and manufacturing.

165 The Extractive Industry Transparency Initiative (EITI) is regarded as one of the reasonably credible voluntary code, because its design and operation involved a multi-stakeholder engagement of the UK government and relevant actors. 


\section{Table 3: 0ther actors and their role in enabling the adoption of sustainable finance}

\begin{tabular}{|c|c|c|}
\hline Actor & Role & Current level of engagement \\
\hline Central Bank of Kenya & $\begin{array}{l}\text { To incorporate environmental } \\
\text { and social risk analysis into risk } \\
\text { management guidelines. }\end{array}$ & $\begin{array}{l}\text { Low but considered to be a key driver in } \\
\text { partnership with the Kenya Bankers Association } \\
(\mathrm{KBA})\end{array}$ \\
\hline $\begin{array}{l}\text { Capital Markets } \\
\text { Authority }\end{array}$ & $\begin{array}{l}\text { To encourage consideration of } \\
\text { sustainability matters in investment } \\
\text { advisory, decision making and ratings }\end{array}$ & Low \\
\hline $\begin{array}{l}\text { Nairobi Securities } \\
\text { Exchange }\end{array}$ & $\begin{array}{l}\text { To encourage integrated reporting as } \\
\text { part of listing requirements }\end{array}$ & Low \\
\hline $\begin{array}{l}\text { Pension and Insurance } \\
\text { Industry }\end{array}$ & $\begin{array}{l}\text { To embrace sustainable finance } \\
\text { principles in their own industry }\end{array}$ & Low \\
\hline $\begin{array}{l}\text { Institute of Certified } \\
\text { Public Accountants, } \\
\text { accounting and auditing } \\
\text { professions }\end{array}$ & $\begin{array}{l}\text { To incorporate a wider range of } \\
\text { considerations into company } \\
\text { performance reporting and encourage } \\
\text { the uptake of integrated reporting. }\end{array}$ & Low \\
\hline $\begin{array}{l}\text { Policy makers and } \\
\text { regulators responsible } \\
\text { for environmental and } \\
\text { social matters }\end{array}$ & $\begin{array}{l}\text { Effective policy and regulation around } \\
\text { the management of natural, human } \\
\text { and social capital. }\end{array}$ & $\begin{array}{l}\text { Engaged by virtue of their mandate but } \\
\text { concerns were raised by respondents about } \\
\text { the adequacy of policy and regulation and } \\
\text { unpredictability of enforcement. }\end{array}$ \\
\hline $\begin{array}{l}\text { Industry sector } \\
\text { associations e.g. } \\
\text { Kenyan Association of } \\
\text { Manufacturers, Kenya } \\
\text { Flower Council }\end{array}$ & $\begin{array}{l}\text { To share experiences with } \\
\text { sustainability challenges and solutions }\end{array}$ & Low \\
\hline
\end{tabular}




\section{Current level of engagement}

Low. It is difficult to access technical information able to inform decision making. There is widespread belief that the research capacity exists; problem is lack of incentive to

Tertiary education and research entities

To develop relevant courses at undergraduate \& post graduate level. Undertake research. undertake research on SFI topics.

Potential partner institutions identified by respondents included: Strathmore, Nairobi School of Economics, Kenya Centre for Monetary Studies, Kenyatta University, United States International University of Kenya

Moderate. There is some reporting by the media and some activism but in general very few voices and insufficient impact.

Moderate. They are aware that Clients engage consultants particularly for Social and Environmental Impact Assessments (SEIA).

Provision of advisory services to Banks and also to Banks Clients
However, none had experience with local consultants providing SFI training. Even in the area of sustainability reporting the assignment is typically resourced from consultants overseas. 
Second, there should be a regulator preferably the Central Bank of Kenya to enforce the guidelines and ensure compliance. Although, individual banks should be left to implement and integrate the guidelines according to their credit risk policies, they should regularly report to the regulators on their progress in adoption, implementation and integration of the guidelines. This would avoid a scenario whereby financial institutions simply declare adherence to the Principles without explaining the steps they are taking to implement them. These should be a mechanism of holding signatories to the Principles accountable for non-implementation.

The Central Bank can then award incentives to compliant banks and if possible make license renewals conditional on sustainable reporting. Nigeria has adopted a similar approach successfully, although the implementation is still ongoing. The regulator can also ensure compliance by publishing a list of banks that do not comply with sustainable banking guidelines. Such a measure would not only expose a company to social backlash and loss of business, but would also expose a bank to legal risks. To encourage compliance amongst banks, the regulators will need to do capacity building and awareness raising campaigns on sustainable banking through seminars, workshops, trainings and conferences to banks. Individual banks should then develop internal capacity to manage their environmental and social responsibilities, with a focus on commercial/credit risk management.

Third, the regulator should also track progress towards the implementation of sustainability. Here, reliance should not be placed only on the environmental impact assessments, but other tools such as sustainability impact assessments, regulatory impact assessments, poverty impact assessments, and strategic environmental assessments should be explored. These tools should be adopted as integral parts of assessing progress towards sustainable banking across all banks based on their capabilities. Such an approach combines both the voluntary elements of self-regulation and sanction-backed elements of the command and control approach.

Lastly, the role of donors needs to be reassessed. It was evident that the CSR programs undertaken by banks were being financed with donor money. Banks with access to donor funding were able to gain a competitive over others. However, it is not clear whether if donor funds were withdrawn the programmes will still be sustainable. Some regulation would level the playing field in this regard. 


\section{References}

1. A Report of UNEP FI \& ATF, "Banking on Value-A New Approach to Credit Risk," (UNEP, 2007).

2. A. Hoijtink, "The Sustainability Attitude of Commercial Banks," University of Tilburg, September 2005.

3. A.M.E. Mendoza \& C.T. Toralba,'Shareholder Value and the Common Good,' in D. Lutz \& P. Mimbi, The Challenge of Business: Going Beyond Wealth Maximisation and Profit Maximisation, (Law Africa, 2011).

4. B.J. Richardson, "Africa: from object to agent of socially responsible investment," in F.N. Botchway (ed), Natural Resource Investment and Africa's Development, (Edward Elgar Publishing, 2011).

5. Babalola, "Corporate Governance and Sustainable Banking Sector: Evidence from Nigeria," Research Journal of Finance and Accounting, Vol.5, No.12, 2014.

6. Best Practice Guide on Sustainable Finance, 2012 available at www. wwf.ru/data/docs/best-practice-guide-for-banks.doc.

7. Central Bank of Kenya, "Shareholding Information," CBK Website, 2014, available at https://www.centralbank.go.ke/index.php/ commercial-banks-mortgage-finance-institutions/shareholdinginformation, accessed on 28/10/2014.

8. Central Bank of Nigeria, "Implementation of sustainable Banking Principles by Banks, Discount Houses and Development Finance Institutions" Circular FPR/DIR/CIR/GEN/01/33, September 2012. 
9. F. Amalric, "The Equator principles: A Step towards Sustainability?" Center for Corporate Responsibility Sustainability Working Paper Series, (Working paper No. $1 / 05,2005)$.

10. I. Sundar, Environment and Sustainable Development, (APH Publishing, 2006).

11. International Finance Corporation, The Business Case for Sustainability, IFC, 2012.

12. J. Harris, "Basic Principles of Sustainable Development," Global Development and Environment Institute, Working Paper 00-04 available at https://notendur. hi.is/bdavids/UAU101/Readings/Harris_2000_Sustainable_development.pdf accessed on 26/06/2014.

13. J.W.Gelder, "The do's and don'ts of Sustainable Banking: A Bank Track Manual", available at www.banktrack.org/.../061129_the_dos_and_donts_of_sustainablebanking, (accessed on 2/08/2014).

14. JM Gathungu \& ZN Ratemo, 'An Assessment of the Impact of Corporate Social Responsibility on the Strategic Intent at Standard Chartered Bank Kenya Limited,' International Journal of Education and Research, Vol.1 (5) May 2013.

15. Kenya Bankers Association, Banking Industry Development and Social Investment Report, 2013.

16. M. Imeson \& A. Sim, "Sustainable Banking: Why Help Communities and Saving the Planet is Good for Business", available athttp://www.sas.com/resources/ whitepaper/wp_24356.pdf accessed on 23rd June 2014.

17. M. Jeucken, Sustainable Finance and Banking; The Financial Sector and the Future of the Planet, Earth scan Publications, London, 2002. 
18. M.P. Todaro, Theories of Development: A Comparative Analysis, (Addison Wesley, 2000).

19. National Climate Change Action Plan, Mainstreaming Kenya's National Climate Change Action Plan into the Financial Services Sector, 2012.

20. 0. Owiti, "Law, Ideology and Development: Dialectics or Eclecticism at Play?” in Y. Vyas et al (eds), Law and Development in the Third World, (University of Nairobi, 1994).

21. O.K. Edu, "Corporate Social Responsibility: Multinational Oil Companies in Nigeria," Vol. 21, No. 1, Journal of the Commonwealth Lawyers Association (2012).

22. P. Bosshard, International Rivers Network, "An NGO Perspective on the Equator Principles," Proceedings of DPP Workshop on Financing Dams and Sustainable Development, held on 22-23 April,2004 in London.

23. R. Yadav \& G.S. Pathak, "Environmental Sustainability through Green Banking: A Study on Private and Public Sector Banks in India,"Available at http://www.ssrn. com/link/OIDA-Intl-Journal-Sustainable-Dev.html, (accessed on 10/07/2014).

24. R.F. Lawrence \& W.L. Thomas, "The Equator Principles and Project Finance: Sustainability in Practice?" Natural Resources \& Environment, Vol. 19, No. 2 (Fall 2004).

25. R.G. Eccles, I. Ioannou \& G. Serafeim,'The Impact of Corporate Sustainability on Organizational Processes and Performance,', available at http://www.hbs.edu/ faculty/Publication\%20Files/SSRN-id1964011_6791edac-7daa-4603-a2204a0c6c7a3f7a.pdf, accessed on 12/08/2014. 
26. Republic of Kenya, Finance-Investment Climate for Climate Investment, NCCAP, 2012.

27. Republic of Kenya, National Climate Change Action Plan 2013-2017, Government of Kenya, 2013.

28. Republic of Kenya, National Climate Change Response Strategy, Government of Kenya, 2010.

29. Republic of Kenya, Vision 2030, Government of Kenya, 2007.

30. T. Strange \& A. Bayley, Sustainable Development: Linking Economy, Society, Environment, (OECD, 2008)

31. UNEP Finance Initiative, Sustainability Banking-Africa Report, (UNEP, Nairobi).

32. WCED, Our Common Future (Oxford: Oxford University Press, 1987). 


\section{Acknowledgement}

The author would like to acknowledge the following people: Nuru Mugambi, Jared Osoro, David Muriithi and Emma Caddy for their insightful comments made during the writing of the paper, Smith Otieno and Tabitha Adhyambo from the University of Nairobi for their commentary and contributions, the banks which responded to the author's survey, and the Kenya Bankers Association (KBA) consultants Melissa Makwarimba et. al. who undertook the sustainable finance needs assessment survey. The author also acknowledges the KBA Center for Research on Financial Markets and Policy ${ }^{\oplus}$, the initial publisher of this paper under the KBA Working Paper Series. 



\title{
Kenya Bankers Association
}

13th Floor, International House, Mama Ngina Street

P.O. Box 73100- 00200 NAIROBI

Telephone: 25420 2221704/2217757/2224014/5

Cell: $0733812770 / 0711562910$

Fax: 254202221792

Email: research@kba.co.ke

Website: www.kba.co.ke
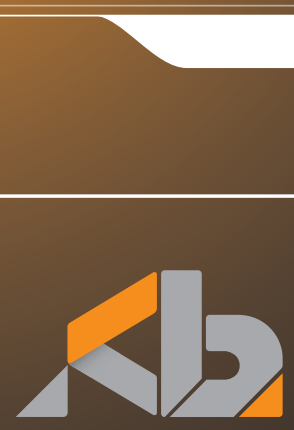

\section{KENYA BANKERS}

\author{
A S SOCIATION
}

One Industry. Transforming Kenya. 